\title{
The Dale Problem: Property and Speech under the Regulatory State
}

\author{
Louis Michael Seidman $\dagger$
}

\section{INTRODUCTION}

A contradiction lies at the core of the modern law of speech and property. The contradiction is captured by four propositions, all of which are widely accepted, but all of which cannot be true.

Proposition 1: freedom of speech is not subject to political revision.' Of course, beneath this seemingly simple statement lies a body of immensely complex doctrine. The proposition says nothing about what freedom of speech consists of or what levels of review should apply to political decisions regulating or channeling speech. Still, few would quarrel with the notion that there is some core content to the freedom of speech and that this core content is constitutionally protected.

Proposition 2: within broad limits, economic entitlements are subject to political revision. ${ }^{2}$ As we shall see, this proposition has not always been true, and it is not completely true now. As a generalization,

$\dagger$ Carmack Waterhouse Professor of Constitutional Law, Georgetown University Law Center. Many people helped me think through the problems addressed in this article. I am especially grateful to Larry Alexander, Randy Barnett, David Bernstein, Julie Cohen, Lee Anne Fennell, Martin Lederman, Gary Peller, Adam Samaha, Geoffrey Stone, Mark Tushnet, and Rebecca Tushnet, and to participants at workshops at The University of Chicago Law School, Georgetown University Law Center, and Loyola University Law School. I received excellent research assistance from James Banda and Richard Harris.

1 For the most famous articulation of this point, see West Virginia Board of Education $v$ Barnette, 319 US 624, 638 (1943):

The very purpose of a Bill of Rights was to withdraw certain subjects from the vicissitudes of political controversy, to place them beyond the reach of majorities and officials and to establish them as legal principles to be applied by the courts. One's right to...free speech ... and other fundamental rights may not be submitted to vote; they depend on the outcome of no elections.

2 For the canonical statement, see Ferguson v Skrupa, 372 US 726, 729-30 (1963):

There was a time when the Due Process Clause was used by this Court to strike down laws which were thought unreasonable, that is, unwise or incompatible with some particular economic or social philosophy.... [That] doctrine ... has long since been discarded. We have returned to the original constitutional proposition that courts do not substitute their social and economic beliefs for the judgment of legislative bodies, who are elected to pass laws. As this Court stated in a unanimous opinion in 1941, "We are not concerned ... with the wisdom, need, or appropriateness of the legislation." Legislative bodies have broad scope to experiment with economic problems ....

Quoting Olsen v Western Reference \& Bond Association, 313 US 236, 246 (1941). 
though, it is not only true but also a central tenet of the modern regulatory state. Of course, the Constitution prevents the taking of property unless the taking is for a public use, and just compensation must be paid for certain kinds of interferences with property rights. ${ }^{4}$ But courts have read the public use requirement very broadly. As a consequence, if the government is willing to pay for property, it can usually seize it. Moreover, even if the government is unwilling to pay, it can usually regulate and restrict property rights very extensively. ${ }^{6}$ If the economic entitlement does not count as property, then the scope of permissible political revision is even broader.

Proposition 3: the freedom of speech does not include the right to use another person's property in order to convey one's message. ${ }^{8}$ This proposition is also less true than one might think, but it is nonetheless often true, and it captures an intuition that most people unreflectively hold. For example, when the Supreme Court upheld the free speech right of a protestor to burn an American flag, it took pains to point out that "nothing in our opinion should be taken to suggest that one is free to steal a flag so long as one later uses it to communicate an idea." Similarly, the Court has made clear that no one has the consti-

3 See, for example, Hawaii Housing Authority v Midkiff, 467 US 229, 239-41 (1984) (holding that a Hawaii law transferring property to reduce concentration of land ownership did not violate the public use requirement of the Fifth Amendment).

4 See, for example, Loretto v Teleprompter Manhattan CATV Corp, 458 US 419, 427-41 (1982) (holding that a New York law requiring a landlord to permit a tenant to install cable television facilities on the building's exterior was a taking that required compensation).

5 See, for example, Kelo v City of New London, 545 US 469, 480-84 (2005) (holding that a city's exercise of eminent domain for the purpose of redeveloping a distressed area satisfied the public use requirement). See also Alison Dunham, Griggs v. Allegheny County in Perspective: Thirty Years of Supreme Court Expropriation Law, 1962 S Ct Rev 63, 65-71.

6 See, for example, Palazzolo v Rhode Island, 533 US 606, 613-16 (2001) (holding that state regulations restricting a landowner from developing his land for commercial use but permitting him to build a residence on it did not establish a taking); Penn Central Transportation Co $v$ City of New York, 438 US 104, 128-38 (1978) (holding that a New York landmark preservation law restricting a landowner from constructing a building on top of Grand Central Terminal did not establish a taking).

7 See, for example, Energy Reserves Group, Inc v Kansas Power \& Light Co, 459 US 400, 413-19 (1983) (holding that the state could alter price terms in a contract between a public utility and a supplier without violating the Contracts Clause); General Motors Corp v Romein, 503 US 181, 183-86 (1992) (upholding a Michigan law amending a workers' compensation statute to require employers to reimburse employees for unpaid benefits).

8 See Robert A. Sedler, Property and Speech, 21 Wash U J L \& Policy 123, 128 (2006) (noting that picketing and protests lose First Amendment protection if conducted on another's private property).

9 Texas v Johnson, 491 US 397, 412 n 8 (1989). 
tutional right to commandeer someone else's printing press, ${ }^{10}$ or automobile, ${ }^{11}$ or shopping center ${ }^{12}$ to engage in communication.

Proposition 4: all speech requires the use of some property. For the most part, speech requires the use of a physical object, whether it is a megaphone, paper and pen, a printing press, a television camera, or a computer terminal. Even speech that depends on nothing more than the human vocal cords must occur somewhere. The physical things that speakers use and the physical places where they use them are owned by someone. Without access to these things and places, no speech is possible.

These four propositions cannot be reconciled. If it is true that economic entitlements, including most property rights, are subject to political revision, and if it is true that there is no right to use another's property for speech, and if it is true that speech requires property, then it cannot also be true that speech rights are immune from political revision.

Two Supreme Court cases illustrate this simple but puzzling syllogism. In City of Ladue $v$ Gilleo, ${ }^{13}$ the Supreme Court invalidated a statute that prohibited a homeowner from posting a sign in her own window. ${ }^{14}$ In United States Postal Service v Council of Greenburgh Civic Associations, ${ }^{15}$ the Court upheld a statute prohibiting the placing of unstamped mailable matter in the letterboxes of private homes. ${ }^{16}$ What is the difference between the two cases? In Gilleo, the Court emphasized that the sign was placed in the speaker's own home. ${ }^{17}$ In contrast, the Greenburgh Court relied on the fact that the government had transferred ownership and control of the letterbox from the private owner to the government itself. ${ }^{18}$ Because the letterbox is no longer private property, the government has the ability to restrict its use for speech purposes.

And so the questions beg to be asked: If the government can shift the property interest in a mailbox, why can it not shift the property interest in a window? And if it can shift the property interest in a win-

10 See Miami Herald Publishing Co v Tornillo, 418 US 241, 257-58 (1974) (holding that a newspaper that criticizes a political candidate has a First Amendment right to deny the candidate free space to respond to the criticism).

11 See Wooley v Maynard, 430 US 705, 714-17 (1977) (striking down a law making it a misdemeanor to obscure the slogan "Live Free or Die" printed on New Hampshire license plates).

12 See Hudgens $v$ NLRB, 424 US 507, 520-21 (1976) (refusing to recognize a First Amendment right to picket inside a shopping mall without the consent of the owner).

13512 US 43 (1994).

14 See id at $45-48$.

15453 US 114 (1981).

16 See id at $128-34$.

17 See 512 US at 58 .

$18 \quad 453$ US at $128-30,131 \mathrm{n} 7$. 
dow, does this not mean that it can shift the speech interest in using a window to display a sign?

As it happens, one can trace the origins of these questions to a tension that emerged at the very dawn of the modern regulatory state. Once ensconced in power, the Supreme Court justices appointed by Franklin D. Roosevelt faced a dilemma. One part of the New Deal attack on the old order consisted of a criticism of status quo distributions of wealth and power in the private sphere. Another part consisted of criticism of a brand of judicial intervention that stood in the way of New Deal reforms. How, then, should the justices have reacted when the Court was urged to intervene in order to change status quo distributions?

To understand the modern answer to this question, ${ }^{19}$ we must divide legal rules into three categories: those that are constitutionally impermissible, those that are constitutionally discretionary, and those that are constitutionally mandatory. Rules are constitutionally impermissible when the Constitution prohibits their enactment. Rules are constitutionally discretionary when the Constitution leaves the political branches free to enact them or not. Rules are constitutionally mandatory when the Constitution requires them even if the political branches do not enact them.

At the risk of considerable oversimplification, it is possible to sketch how the Lochner Court and the modern Court have slotted various disputes into these categories. During the Lochner era, redistributive economic legislation that deviated from a "natural," prepolitical baseline was sometimes treated as impermissible, and legal rules protecting existing distributions were occasionally treated as mandatory. ${ }^{21}$ For example, in Lochner v New York ${ }^{22}$ itself, the Supreme Court held that legislation setting maximum working hours for bakers was impermissible. ${ }^{23}$ In a smattering of other cases, the Court interpreted the Consti-

19 I use the term "modern" to refer to the jurisprudential approach that emerged with the rejection of the approach taken in Lochner $v$ New York, 198 US 45 (1905), and that prevails in some form to this day.

20 Id at 64. See also, for example, Ribnik v McBride, 277 US 350, 358-59 (1928) (invalidating price regulation); Adkins v Children's Hospital, 261 US 525, 561-62 (1923) (invalidating a minimum wage statute for women); Coppage v Kansas, 236 US 1, 26 (1915) (invalidating legislation forbidding contracts under which employees agreed not to join unions). It does not follow that the Lochner-era Court always constitutionalized the common law. See generally David E. Bernstein, Lochner's Legacy's Legacy, 82 Tex L Rev 1 (2003) (attacking the widely held belief that the Lochner Court saw the common law as part of nature rather than a legal construct). When the Court invalidated social legislation, however, it invariably treated deviations from market baselines as requiring justification. See Cass R. Sunstein, Lochner's Legacy, 87 Colum L Rev 873, 874-75 (1987).

21 See, for example, Truax v Corrigan, 257 US 312, 339-42 (1921) (invalidating a statute that prevented an injunction in a labor dispute where the right to private property was threatened).

22198 US 45 (1905).

23 See id at 64. 
tution to impose mandatory rules protecting property rights even when the political branches had not provided for them.

The modern Court has moved both classes of rules into the discretionary category. Judges do not read the Constitution to prohibit such measures, ${ }^{25}$ but neither do they read it to require them. ${ }^{26}$ Thus, what came to be called "general social and economic legislation" was subject to only minimal review, even when the laws arguably protected existing distributions. ${ }^{27}$ With respect to these laws, objections to judicial activism prevailed over objections to maldistribution.

Statutes trenching on noneconomic liberties like freedom of speech and racial equality were treated very differently. The Lochner Court sometimes categorized these measures as discretionary. ${ }^{28}$ For example, in Plessy $v$ Ferguson, ${ }^{29}$ the Court held that states had discretion whether to mandate separation of the races on privately owned railroads. ${ }^{30}$ Similarly, in the World War I free speech cases, the Court held that Congress could choose whether to outlaw speech supposedly obstructing the war effort."

24 See, for example, Truax, 257 US at 327-30 ("[A] purely arbitrary or capricious exercise of [legislative] power whereby a wrongful and highly injurious invasion of property rights ... is practically sanctioned and the owner stripped of all real remedy, is wholly at variance with [fundamental principles of right and justice].").

25 See, for example, West Coast Hotel Co v Parrish, 300 US 379, 398-400 (1937) (upholding a law setting a minimum wage for women); NLRB v Jones \& Laughlin Steel Corp, 301 US 1, 49 (1937) (upholding the National Labor Relations Act); Skrupa, 372 US at 730-31 ("States 'have power to legislate against what are found to be injurious practices in their internal commercial and business affairs, so long as their laws do not run afoul of some specific federal constitutional prohibition."'), quoting Lincoln Federal Labor Union v Northwestern Iron \& Metal Co, 335 US $525,536(1949)$.

26 See, for example, Lindsey $v$ Normet, 405 US 56, 74 (1972) (holding that the Constitution does not "guarantee [ ] access to dwellings of a particular quality"); Dandridge $v$ Williams, 397 US 471, 483-87 (1970) (holding that there is no constitutional right to welfare); San Antonio Independent School District v Rodriguez, 411 US 1,33-39 (1973) (holding that there is no constitutional right to education).

27 See, for example, Board of Trustees of the University of Alabama v Garrett, 531 US 356, 366 (2001) (holding that "minimum 'rational basis' review" was applicable "to general social and economic legislation").

28 But not always. See, for example, Meyer v Nebraska, 262 US 390, 399 (1923) (holding that the liberty guaranteed by the Fourteenth Amendment included "the right of the individual to ... acquire useful knowledge, to marry, establish a home and bring up children, to worship God according to the dictates of his own conscience, and generally to enjoy those privileges long recognized at common law as essential to the orderly pursuit of happiness by free men"); Pierce $v$ Society of Sisters, 268 US 510, 534-35 (1925) (upholding the right to choose private education for one's children).

29163 US 537 (1896).

30 See id at 550-52.

31 See, for example, Schenck v United States, 249 US 47, 52-53 (1919) (upholding a conviction under the Espionage Act of 1917 for speech urging resistance to the draft); Abrams $v$ United States, 250 US 616,623-24 (1919) (upholding a conviction for violating a 1918 amendment to the Espionage Act for conspiring to urge curtailment of war materials); Debs v United States, 249 US 
In contrast, the modern Court subjects similar statutes to heightened review. ${ }^{32}$ The statutes were effectively shifted from the discretionary to the impermissible category, and occasionally, rules guaranteeing exercise of these rights were treated as constitutionally mandatory. ${ }^{33}$

At first, the modern Court focused primarily on free speech claims, but later, statutes involving race, ${ }^{35}$ gender, ${ }^{36}$ and sexual autonomy ${ }^{37}$ were added to the list of measures that risked judicial invalidation. For New Deal liberals, many of these laws were thought to be unjust because they entrenched maldistributions of social power. Hence, in this area, the objection to maldistribution prevailed over the objection to judicial intervention.

For more than a half century, this approach has dominated constitutional law. It has nonetheless been subject to vigorous attack. Defenders of economic rights have complained that there is no principled basis for distinguishing between property-based and liberty-based constitutional rights, ${ }^{38}$ that the right to hold and use property is itself an important liberty, ${ }^{39}$ and that other liberties are extremely fragile in a world where the legislative power to redistribute property is left unchecked. ${ }^{40}$ Critics on the left, much more muted these days, have complained that noneconomic liberties are meaningless in a society where

211, 216-17 (1919) (upholding the conviction of a leader of the Socialist Party for giving a speech criticizing the war).

32 See, for example, Skinner $v$ Williamson, 316 US 535, 541-43 (1942) (invalidating a sterilization statute); Barnette, 319 US at 642 (invalidating a compelled flag salute); Smith v Allwright, 321 US 649, 661-66 (1944) (invalidating a primary limited to white voters).

33 See Marsh v Alabama, 326 US 501, 506-10 (1946) (holding that the Constitution, of its own force, protected the right of an individual to distribute leaflets in a company-owned town); Shelley $v$ Kraemer, 334 US 1, 20-21 (1948) (holding that the Constitution prohibits racially restrictive covenants).

34 See, for example, De Jonge v Oregon, 299 US 353, 365 (1937) (invalidating a conviction under a criminal syndicalism statute for participating in peaceable political discussion); Herndon $v$ Lowry, 301 US 242, 263-64 (1937) (invalidating a conviction for attempting to incite insurrection); Barnette, 319 US at 642 .

35 See, for example, Brown v Board of Education, 347 US 483, 494-95 (1954).

36 See, for example, Craig v Boren, 429 US 190, 210 (1976) (invalidating a statute that prescribed gender-based rules for the sale of alcohol).

37 See, for example, Griswold v Connecticut, 381 US 479, 484-86 (1965) (invalidating a statute prohibiting the use of contraceptives); Lawrence $v$ Texas, 539 US 558, 577-79 (2003) (invalidating a statute prohibiting sodomy).

38 See John O. McGinnis, The Once and Future Property-based Vision of the First Amendment, 63 U Chi L Rev 49, 86-92 (1996); Richard A. Epstein, Property, Speech, and the Politics of Distrust, 59 U Chi L Rev 41, $42-43$ (1992).

39 See generally Richard A. Epstein, Takings: Private Property and the Power of Eminent Domain (Harvard 1985). See also Robert G. McCloskey, Economic Due Process and the Supreme Court: An Exhumation and Reburial, $1962 \mathrm{~S} \mathrm{Ct} \mathrm{Rev} \mathrm{34,} 46$ (arguing that economic rights are as important as other personal liberties); Frank H. Easterbrook, Implicit and Explicit Rights of Association, 10 Harv J L \& Pub Policy 91, 98 (1987) (same).

40 See generally Margaret Radin, Property and Personhood, 34 Stan L Rev 957 (1982) (arguing that personhood requires control over resources in one's environment). 
there is serious maldistribution of property ${ }^{41}$ and that economic redistribution therefore should be mandatory rather than merely discretionary. ${ }^{42}$ On the far left, some critics have argued that some noneconomic liberties, which the Court has treated as mandatory, have obstructed rather than aided redistribution.

In this Article, I advance a different and, I hope, original objection to the modern approach. For the reasons I have already explained, it will not do to distinguish between economic and noneconomic liberties because noneconomic freedoms are parasitic on underlying economic entitlements. Although I believe that my claim is generalizable, I will focus here on the relationship between free speech and property-like entitlements. In order to give free speech rights content, I argue, the Court must shield economic entitlements from political revision, contrary to Proposition 2 and to the New Deal compromise. It can do so in one of two ways: by making supposedly prepolitical distributions mandatory, as the Lochner Court did, or by making these distributions impermissible, as radical critics of the New Deal compromise demand. What does not work is making property distributions discretionary and liberty rights mandatory. This compromise reproduces, rather than eliminates, the contradiction that provided the motive for it in the first place.

Part I of this Article uses a single Supreme Court decision-Boy Scouts of America $v$ Dale ${ }^{44}$ - to illustrate the problem. The Dale Court held that a New Jersey public accommodations law, interpreted to prohibit Boy Scouts of America (BSA) from dismissing a scoutmaster on account of his sexual orientation, violated BSA's First Amendment right to "expressive association." I I argue that the decision depends on an implicit constitutionalization of property distributions and that this approach, by making supposedly prepolitical property rights mandatory, cannot easily be reconciled with one branch of the New Deal compromise. Nor can the problem be resolved by overruling Dale. Doing so would make free speech rights discretionary across a broad

41 See Amy Gutmann, Liberal Equality 186-91 (Cambridge 1980) (arguing that minimum economic entitlements are necessary for exercise of civil liberties); Cass Sunstein, Free Speech Now, 59 U Chi L Rev 255, 263-278 (1992) (arguing that the Court's First Amendment doctrine mistakenly treats market allocations as a given).

42 See Frank Michelman, Foreword: On Protecting the Poor through the Fourteenth Amendment, 83 Harv L Rev 7,9-13 (1969); Peter B. Edelman, The Next Century of Our Constitution: Rethinking Our Duty to the Poor, 39 Hastings L J 1, 2-8 (1987).

43 See Mark Tushnet, An Essay on Rights, 62 Tex L Rev 1363, 1384-1402 (1984) (arguing that rights can be socially harmful). Compare generally Gerald N. Rosenberg, The Hollow Hope: Can Courts Bring About Social Change? (Chicago 1991) (arguing that pursuit of judicial enforcement of rights siphons off political energy).

44530 US 640 (2000).

45 See id at 644. 
range of cases, thereby coming into conflict with the other branch of the compromise.

Parts II and III survey some of these cases. I argue that the Court has taken inconsistent positions concerning the permissibility of shifting property and other economic entitlements when they impact upon putative free speech rights, and that when it has permitted a shifting of these entitlements, free speech rights have not survived. Part II concerns cases where property distributions are left in the discretionary realm, thereby placing free speech rights in that realm as well. Part III focuses on cases like Dale where the Court has constitutionalized property rights by making redistribution either constitutionally impermissible or mandatory. In Part IV, I briefly conclude and suggest some implications my analysis holds for the future of free speech rights.

\section{THE DALE PROBLEM AND FOUR FAILED SOLUTIONS}

BSA unceremoniously removed James Dale from his position as scoutmaster after discovering that he was gay. ${ }^{46}$ Dale filed suit, claiming that BSA had violated a New Jersey statute that prohibited discrimination based upon sexual orientation in public accommodations. The New Jersey Supreme Court sided with Dale, ${ }^{48}$ but a 5-4 majority of the US Supreme Court, in an opinion written by Chief Justice William Rehnquist, reversed. ${ }^{49}$ According to the majority, application of the New Jersey statute in this context violated BSA's free speech right to "expressive association."

Dale has been widely criticized, ${ }^{51}$ but neither the Dale Court nor its critics have noticed a key problem posed by the case. Suppose we assume that BSA was, indeed, engaged in First Amendment expression when it excluded Dale, and suppose that the New Jersey statute did, in fact, interfere with that expression. These suppositions do not resolve the case, as the Court thought, because there are complementary free speech interests on the other side of the ledger. Surely, Dale, too, was making a political point when he insisted on Boy Scout mem-

46 See id at 645 .

47 See id.

48 Dale v Boy Scouts of America, 734 A2d 1196, 1230 (1999), reversed Boy Scouts of America $\vee$ Dale, 530 US 640 (2000).

49 Dale, 530 US at 661.

50 See id at 644.

51 See generally, for example, Andrew Koppelman, Signs of the Times: Dale v. Boy Scouts of America and the Changing Meaning of Nondiscrimination, 23 Cardozo L Rev 1819 (2002); Steven Clark, Judicially Straight?: Boy Scouts v. Dale and the Missing Scalia Dissent, 76 S Cal L Rev 521 (2003). 
bership. ${ }^{52}$ Dale's status as an openly gay man who served effectively as a scoutmaster forcefully communicated opposition to negative stereotypes about male homosexuals. Why were his free speech rights not abridged when the Court upheld BSA's right to expel him?

\section{A. The Marsh Solution}

An early decision by the modern Court recognized just such a claim, albeit in a dramatically different setting. In Marsh v Alabama, a religious leafleter was prosecuted for trespass when he refused to obey an order to leave the town of Chickasaw, which was wholly owned by the Gulf Shipbuilding Corporation. ${ }^{55}$ In an opinion expressly invoking "preferred position" rhetoric that sharply distinguished between property claims and civil liberties, ${ }^{56}$ the Court held that Marsh's conviction violated his free speech rights. Writing for the majority, Justice Hugo Black was unimpressed by the argument that Gulf was simply enforcing the right of exclusion associated with private property. Instead, the Court held that ordinary principles of state property law did not trump free speech claims. ${ }^{57}$ Background property entitlements were unconstitutional to the extent that they interfered with Marsh's ability to communicate his message. Put differently, the Marsh Court rejected Proposition 3: at least in this context, it held that a speaker did have the right to commandeer the property of another for speech purposes.

Just as Gulf interfered with Marsh's right of free expression, so too it might be said that BSA interfered with Dale's free expression rights. Of course, the prerequisite of state action means that in both cases, a constitutional violation requires some sort of support or complicity by the state. But Marsh seems to stand for the proposition that the enforcement of background state property and contract laws is sufficient to satisfy the state action requirement. Thus, if Marsh-style reasoning were applied to the facts of Dale, the Court would have had to weigh Dale's First Amendment interests against those of BSA.

We cannot know how the Court would have struck the balance, but it is at least possible that it would have concluded that Dale's First

52 For a subtle and powerful development of this point on a more general level, see Nan D. Hunter, Expressive Identity: Recuperating Dissent for Equality, 35 Harv CR-CL L Rev 1 (2000).

53 Perhaps the Court should not be faulted for failing to notice this problem since Dale himself did not advance a First Amendment claim. My argument therefore should be taken as a general exposition of the Dale problem rather than a criticism of the Court's resolution of the case.

54326 US 501 (1946).

55 Id at 502-04.

56 See id at 509 ("When we balance the Constitutional rights of owners of property against those of the people to enjoy freedom of press and religion, as we must here, we remain mindful of the fact that the latter occupy a preferred position.").

57 See id. 
Amendment rights should prevail. Significantly, such a holding would have made BSA's exclusion of Dale illegal even if New Jersey had never enacted a public accommodations statute, just as Marsh's expulsion from Chickasaw was illegal even in the absence of a statute protecting his right to be there. To put the same point slightly differently, this decision would have made antidiscrimination law mandatory, rather than merely discretionary as the Dale dissenters argued, or impermissible as the Dale Court held.

One way to conceptualize Marsh, then, is that it, like Lochner, constitutionalizes state decisions concerning allocation of property rights. But although both cases move the question out of the discretionary sphere, there is nonetheless a crucial difference between them. Whereas Lochner made redistribution constitutionally impermissible, Marsh made it mandatory. Lochner provided constitutional protection for the rights of the "original" property holder, who was thought to have a natural or prepolitical entitlement. In contrast, Marsh protected the dispossessed by requiring redistribution from owners to nonowners. Marsh in effect created a constitutionally compelled First Amendment easement.

Marsh, then, spells big trouble for Dale. Fortunately for the Dale Court, however, Marsh-style reasoning is not much in fashion these days. As we shall see, Marsh has never been overruled, and remnants of the Marsh approach continue to influence some corners of free speech jurisprudence. ${ }^{58}$ Still, Marsh's modern domain has been sharply limited. ${ }^{59}$

Its partial demise is almost certainly related to its failure to deal with one horn of the New Deal compromise. Marsh tended toward maximization of the government's potential to reallocate distributions produced by private markets, but it did so by also maximizing judicial power. Taken to the limits of its logic, Marsh constitutionalizes virtually all of public policy. Every decision concerning the allocation of property rights has implications for the total amount of speech society produces. Hence, all such decisions become constitutionally mandatory and, therefore, outside the sphere open to political control. Had Marsh prevailed, it would have proved the justices in the Lochner majority right. Just as they warned, ${ }^{61}$ there would have been no middle ground between making redistribution impermissible and making it mandatory. Once

58 See Part III.B.

59 See Part II.A.

60 For an analogous point, see Larry A. Alexander, Trouble on Track Two: Incidental Regulations of Speech and Free Speech Theory, 44 Hastings L J 921, 929 (1993) (arguing that "all laws affect what gets said, by whom, to whom, and with what effect") (emphasis omitted); Larry Alexander, Is There a Right of Freedom of Expression? 17-19 (Cambridge 2005) (same).

61 See Lochner, 198 US at 52-54. 
the constitutional restraints on redistribution are lifted, we are on a road headed inexorably toward judicially imposed socialism.

\section{B. The "Deconstitutionalization" Solution}

Of course, this outcome was unacceptable. The liberals on the Court attempted to avoid it by deconstitutionalizing "neutral" background property law entitlements. The establishment of such entitlements is generally said not to involve "state action" and, therefore, does not raise constitutional problems. ${ }^{62}$ Put differently, decisions about these entitlements are usually treated as discretionary rather than either impermissible or mandatory. For example, a state is entitled to enact a system subsidizing the speech of impoverished political candidates, but it is not required to do so. ${ }^{63}$ The inability of impoverished candidates to speak is said not to involve state action. Whether to provide subsidies is therefore a political, rather than a judicial, decision.

New Deal liberals thought that placing property law in the permissive sphere while shifting laws invading civil liberties to the impermissible sphere produced a sensible and workable compromise between the two conflicting branches of the New Deal critique of the old order. They were wrong. Deconstitutionalizing property rights satisfies the demands of judicial restraint, but only at the cost of jeopardizing civil liberties.

Their mistake is, again, illustrated by Dale. We have already seen that constitutionalizing background property rules spells big trouble for Dale, but surprisingly, deconstitutionalizing them also spells big trouble. It would seem to follow from deconstitutionalization that the state is free, at least within broad constraints, to shift property rights

62 See, for example, Flagg Brothers, Inc v Brooks, 436 US 149, 151-53 (1978) (holding that a statute establishing a property interest for a warehouseman in goods entrusted to him for storage did not make his sale of those goods attributable to the state); San Francisco Arts \& Athletics, Inc $v$ United States Olympic Committee, 483 US 522, 543-44 (1987) (holding that a statute granting the exclusive right to use the word "Olympics" to a private group did not make that group's actions attributable to the state).

The statement in the text may seem counterintuitive because of a few exceptional and famous cases where liberals on the Court treated background state property rules as raising constitutional issues. See, for example, Shelley $v$ Kraemer, 334 US 1, 20-21 (1948) (holding that state enforcement of racially restrictive covenants violated the Fourteenth Amendment). But these exceptional cases were decided against the backdrop of more usual situations where liberals were prepared to acknowledge that state enforcement of property rights did not trigger constitutional protections. See, for example, Bell v Maryland, 378 US 226, 327 (1964) (Black dissenting) (suggesting that the state had not acted unconstitutionally in enforcing trespass laws for a restaurant owner who discriminated on the basis of race).

63 See Buckley $v$ Valeo, 424 US 1, 90 (1976) (declaring that "[i]t is for Congress to decide" whether expenditures for public funding of elections are in the general welfare). 
from one party to the other. True, the partial demise of Marsh means that this shift is not mandatory, but it remains discretionary.

In fact, post-New Deal takings jurisprudence recognizes just this freedom. In recent years, the freedom has eroded slightly as the Court has recognized some limits on the government's power to engage in "regulatory takings." Still, it remains true that unless the government engages in a permanent physical taking or trespass, ${ }^{65}$ or unless its regulatory measures destroy most, if not all, of the value of property, the government retains broad discretion to regulate the use of property without paying compensation."

Suppose, then, that we treat the New Jersey antidiscrimination statute as constituting such a regulation. In effect, the statute grants Dale a property-law, antidiscrimination easement. On this reading of the statute, BSA's property rights have now been modified so as to prohibit use of the property in a manner that prevents individuals from becoming members on the ground that they are gay. Just as a landowner does not have the right to interfere with an easement holder's right of access to the property, BSA does not have the right to interfere with Dale's entitlement to affiliation with BSA. If our original Proposition 2 (establishing the political revisability of economic entitlements) is correct, then this transfer of property interests is constitutionally permissible. And, indeed, under current doctrine, it is unlikely that such an easement would be treated as a "seizure" of the property. It is an "adjust[ment of] the benefits and burdens of economic life to

64 See Lucas v South Carolina Coastal Council, 505 US 1003, 1027 (1992) ("Where the State seeks to sustain regulation that deprives land of all economically beneficial use,... it may resist compensation only if the logically antecedent inquiry into the nature of the owner's estate shows that the proscribed use interests was not part of his title to begin with."). Compare Palazzolo $v$ Rhode Island, 533 US 606, 631 (holding that although "a State may not evade the duty to compensate on the premise that the landowner is left with a token interest," a "regulation permitting a landowner to build a substantial residence on an 18-acre parcel does not leave the property 'economically idle'"), quoting Lucas, 505 US at 1019.

65 See Loretto v Teleprompter Manhattan CATV Corp, 458 US 419, 426 (1982).

66 See note 64 and accompanying text.

67 The Court has eschewed a "set formula" to govern its determination of whether there has been a taking. Instead, it has emphasized that "in a wide variety of contexts, [ ] government may execute laws or programs that adversely affect recognized economic values" and has upheld "land use regulations that destroyed or adversely affected recognized real property interests" where "a state tribunal reasonably concluded that 'the health, safety, morals, or general welfare' would be promoted by prohibiting particular contemplated uses of land." Penn Central Transportation Co v New York City, 438 US 104, 125, 126 (1978), quoting Nectow v City of Cambridge, 277 US 183, 188 (1928).

68 The Supreme Court has squarely held that antidiscrimination provisions governing public accommodations are not unconstitutional interferences with private property. See Heart of Atlanta Motel, Inc $v$ United States, 379 US 241, 258 (1964). See also id at 277 (Black concurring) (explaining that a regulation prohibiting discrimination "does not even come close to being a taking in the constitutional sense"). 
promote the common good" that is neither a physical invasion of real property nor a total destruction of the property's value. ${ }^{70}$ Moreover, even if the statute did amount to a taking, the very most that can be said is that BSA would be entitled to compensation for the reduction in the value of its property, which was likely to be quite minimal."

Perhaps it seems silly to go to this length to refute a claim no one has advanced. The refutation is nonetheless critical because it destroys not only a Fifth Amendment Takings Clause argument that was never made, but also a First Amendment Free Speech Clause argument that was made successfully. Oddly, New Jersey's shift of the property law entitlement now means that BSA, rather than Dale, is forced to rely on Marsh-style reasoning.

The critical point is that the New Jersey statute turns access to the Boy Scouts into Dale's property. Like any holder of an easement, Dale has a property right to be free from interference with his holding. For this reason, our Proposition 3 (establishing that freedom of speech does not include the right to use another's property) applies: in a world where Marsh has been repudiated, BSA can no longer claim that the Free Speech Clause requires the forced use of what is now Dale's property to engage in expressive activity. Just as a trespasser has no general constitutional right to use the property of another so as to maximize the trespasser's speech, so too BSA has no right to infringe Dale's newly granted property right for the sake of its expressive association. How, then, were BSA's First Amendment rights violated when Dale chose to exercise his property right by remaining within the organization?

\section{The Overruling Dale Solution}

If this analysis is correct, it demonstrates that it is not possible, at least in this context, to move property distributions into the discretionary sphere while making laws that impinge on speech rights impermissible. By constitutionalizing speech rights, the Court implicitly constitutionalized supposedly prepolitical property distributions as well.

69 Penn Central, 438 US at 124.

70 The Court has made clear that these are the touchstones for determining whether a taking has occurred. See, for example, Lingle v Chevron U.S.A., Inc, 544 US 528, 538 (2005).

71 To be sure, any such "seizure" would have to be justified by a "public use." See US Const Amend V. However, the Court has read the "public use" element broadly and found it satisfied so long as "the eminent domain power is rationally related to a conceivable public purpose." Hawaii Housing Authority v Midkiff, 467 US 229, 240 (1984). See also Kelo v City of New London, 545 US 469, 482-83 (2005). There can be no doubt that the prohibition of discrimination on the basis of sexual preference is rationally related to a conceivable public purpose. 
We might, of course, conclude that Dale was simply wrongly decided. The result in Dale is problematic in any event. It seems to bring into question not just New Jersey's expansive public accommodations law but also other bedrock nondiscrimination statutes protecting Americans from racial and gender discrimination, ${ }^{2}$ especially given the Court's reluctance to look behind BSA's claim to expressive association. ${ }^{73}$ In many quarters, Dale's demise would not be much mourned.

But we are talking about more than just Dale. Recognizing a government right to shift property entitlements in the fashion of the New Jersey antidiscrimination law has the potential to remake broad swaths of First Amendment law, thus coming into conflict with Proposition 1 (establishing the immunity of free speech from political revision). Three examples suffice to make the point.

In Miami Herald Publishing Co $v$ Tornillo, ${ }^{74}$ the Supreme Court addressed the constitutionality of a "right of reply" statute that required newspapers to print responses from candidates whom the newspapers had attacked. A unanimous Court held that the statute violated core First Amendment principles." Overturning Dale on the grounds suggested above might bring this result into question. If the government can create a nondiscrimination easement, then it would seem that it can also create a right-of-reply easement. It will not do to claim that the creation of this property right itself violates the First Amendment any more than, in a world without Marsh, the granting of a property entitlement to the Gulf Shipbuilding Company violated a trespassing leafleter's First Amendment rights.

In Texas $v$ Johnson, ${ }^{76}$ the Supreme Court invalidated a federal statute prohibiting flag burning." In response to the decision, some members of Congress proposed a regulation of the private property interest in the flag to prohibit uses thought to denigrate it. ${ }^{78}$ Would such a statute effectively overrule Johnson? As noted above, Johnson itself recognized that one has no constitutional right to burn someone else's

72 See Nan D. Hunter, Accommodating the Public Sphere: Beyond the Market Model, 85 Minn L Rev 1591, 1591 (2001). See also David E. Bernstein, Antidiscrimination Laws and the First Amendment, 66 Mo L Rev 83, 126 (2001) (arguing that "religious associations will utilize Dale to obtain exemptions from antidiscrimination laws that they were not able to obtain under the Free Exercise Clause").

73 See Dale, 530 US at 651 (accepting BSA's assertion that it teaches that homosexual conduct "is not morally straight").

74 418 US 241 (1974).

75 Id at 258.

76491 US 397 (1989).

77 See id at 399.

78 See A Bill to Grant the United States a Copyright to the Flag of the United States and to Impose Criminal Penalties for the Destruction of a Copyrighted Flag, HR 3883, 104th Cong, 2d Sess (July 23, 1996), in 142 Cong Rec H 8247. 
flag. ${ }^{79}$ A shift in property entitlements would make it someone else's flag. Perhaps it bears repeating that this shift is not, itself, subject to First Amendment challenge, at least if one takes seriously the deconstitutionalization of property rights claims.

In Hague $v$ Committee for Industrial Organization, ${ }^{81}$ oft-quoted dicta created what, significantly, has been characterized as a "FirstAmendment easement," property in some circumstances to engage in expressive activity. ${ }^{83} \mathrm{Ha}$ gue has given rise to a complex and much contested body of law regulating access to a "public forum.," Although this doctrine has survived (at least in some form) for more than half a century, it is far from clear that it could survive the overruling of Dale on the grounds suggested above. Overruling Dale would mean that shifts in property rights are discretionary even when they impact freedom of expression. Suppose, then, that two rival groups have inconsistent views about the use of government property. Protestors want to use the property for free speech purposes. Nonprotestors object to this use of the property. Placement of property rights in the discretionary, nonconstitutional category means that the political branches are free to resolve this dispute in any way they choose. ${ }^{85}$ Indeed, they are less constrained than on the facts of Dale. If the government could grant a nondiscrimination easement that reduces the property rights of a private person without running afoul of either the Takings Clause or the Free Speech

79 See text accompanying notes 9-12. See also United States $v$ Eichman, 496 US 310, 316 n 5 (1990).

80 In Schacht v United States, 398 US 58 (1970), the Court thought it clear that a statute prohibiting the unauthorized wearing of a military uniform was facially constitutional. See id at 61. The petitioner's conviction under the statute was invalidated only because he fit within an exception to the statute relating to theatrical productions and a qualification on the exception, limiting it to portrayals that did not discredit the armed forces, was unconstitutional. See id at 61-62. If the government can assert a property-like interest in its uniforms, even when otherwise privately owned, then presumably it can assert a similar interest in its flags.

81307 US 496 (1939).

82 Harry Kalven, Jr., The Concept of the Public Forum: Cox v. Louisiana, 1965 S Ct Rev 1, 13.

83 The plurality in Hague famously wrote:

Wherever the title of streets and parks may rest, they have immemorially been held in trust for the use of the public and, time out of mind, have been used for purposes of assembly, communicating thoughts between citizens, and discussing public questions. Such use of the streets and public places has, from ancient times, been a part of the privileges, immunities, rights, and liberties of citizens.

307 US at 515 (plurality).

84 See notes $237-46$ and accompanying text.

85 This was, in fact, the law through much of the Lochner period. See Davis v Massachusetts, 167 US 43, 47 (1897) (endorsing the view of the lower court that "[f]or the legislature absolutely or conditionally to forbid public speaking in a highway or public park is no more an infringement of the rights of a member of the public than for the owner of a private house to forbid it in his house"). 
Clause, then surely it can grant private individuals property rights in its own property without violating either clause. To be sure, granting exclusive rights to the nonprotesters may reduce the total amount of free speech activity, but granting exclusive property rights to The $M i$ ami Herald also might have reduced total First Amendment activity. If we are to avoid the Marsh trap of constitutionalizing the entire social realm, then the government must be left free from First Amendment constraints when it allocates property rights.

\section{The Formal Solution}

Is there a way to distinguish Dale from these other cases so that Dale could be overruled without jeopardizing broad areas of settled First Amendment law? The most promising approach is to emphasize the requirement of government neutrality. Not coincidentally, this requirement has been a central preoccupation of modern constitutionalism. In order to understand it, we must distinguish between two different conceptions of constitutional law. ${ }^{86}$

According to what I will call the "as-applied" conception, the Constitution's concern is with the right of individuals to engage in specified activity without government interference. This conception, like its rival, requires us to examine government actions, but the focus is on how these actions affect individuals. To the extent that decisions attributable to the government hinder individuals in the exercise of their constitutional rights, the decisions are subject to special scrutiny.

A second approach, which I will call the "formal" conception, is the mirror image of the first. Under the formal approach, the Constitution's primary focus is on government decisions rather than on individual freedom. To be sure, this conception requires us to notice when individuals are hindered in the exercise of their rights, but its main concern is with certain kinds of government malfunctions thought to have unfortunate systemic effects. On the formal approach, then, even if some government action hinders an individual in the exercise of constitutional rights, the action is permissible so long as it is not a symptom of broader government malfunction.

Many debates in modern constitutional law can be organized around the disagreement between defenders of the as-applied and for-

86 The discussion that follows in text relies heavily upon Matthew Adler's path-breaking account. See Matthew D. Adler, Rights against Rules: The Moral Structure of American Constitutional Law, 97 Mich L Rev 1 (1998). Adler's distinction between "direct" and "derivative" accounts of the moral content of rights roughly corresponds to my distinction between "as-applied" and "formal" conceptions of constitutional law. See id at 5-7. See also Alexander, Freedom of Expression at 55 (cited in note 60) (arguing that regulatory purpose rather than the effect of a regulation defines the scope of freedom of expression). 
mal conceptions. Disputes about the state action requirement, ${ }^{87}$ about "purpose" and "effect" tests under the Equal Protection Clause, and about "direct" and "incidental" tests for invasions of fundamental rights" (what are sometimes called "track one" and "track two" cases in the First Amendment context ${ }^{\text {90 }}$ ) all relate to this argument.

For our purposes, the distinction is important because it bears on the disagreement between the Marsh Court and its critics. The Marsh Court was strongly influenced by the as-applied conception. Marsh's claim was not that neutral background property rules demonstrated some sort of pervasive government malfunction. Instead, his claim was

87 Consider, for example, Shelley, where the Court held that judicial enforcement of a racially restrictive covenant constituted "state action," violating the Equal Protection Clause of the Fourteenth Amendment. Although the case is often treated as if the state action question was hard, there can be no doubt that the actions of a court count as government conduct. What makes the case hard is that this conduct was formally neutral as between the races (covenants restricting occupancy by any race were enforced) even though, as actually applied, it had a disproportionate impact on African-Americans. See Shelley, 334 US at 20-21.

88 Where laws are formally neutral, their as-applied effect on constitutionally protected groups does not trigger strict scrutiny under current equal protection doctrine. See Personnel Administrator of Massachusetts v Feeney, 442 US 256, 272 (1979) ("[E]ven if a neutral law has a disproportionately adverse effect upon a racial minority, it is unconstitutional under the Equal Protection Clause only if that impact can be traced to a discriminatory purpose."); Washington $v$ Davis, 426 US 229, 242 (1976). Proponents of this approach argue that what equality amounts to is the absence of government malfunction. See, for example, Robert W. Bennett, "Mere" Rationality in Constitutional Law: Judicial Review and Democratic Theory, 67 Cal L Rev 1049, 1076 (1977) ("If members of racial minorities stochastically obtain benefits and suffer detriments as one or another piece of legislation is passed without attention to its racial impact, they are obtaining, not being deprived of, equal protection of the laws."). Opponents of current doctrine argue that even in the absence of government malfunction as conventionally defined, disproportionate impact makes government action problematic. See, for example, Mary E. Becker, Prince Charming: Abstract Equality, 1987 S Ct Rev 201, 247 (arguing that formal equality cannot, for example, "ensure that jobs are structured so that female workers and male workers are equally able to combine wage work and parenthood").

89 See generally Michael C. Dorf, Incidental Burdens on Fundamental Rights, 109 Harv L Rev 1175 (1996). For example, the Court has sometimes held that "incidental limitations on First Amendment freedoms" do not violate free speech rights. See United States v O'Brien, 391 US 367, 376 (1968). For a more complete discussion, see notes $248-49$ and accompanying text. Similarly, under current doctrine, facially neutral laws that fail to evidence government malfunction but that nonetheless have an adverse impact on religious believers are said not to violate the Free Exercise Clause. See Employment Division, Department of Human Resources of Oregon v Smith, 494 US 872, 881-82 (1990). Compare Church of the Lukumi Babalu Aye, Inc v City of Hialeah, 508 US 520, 524 (1993) (invalidating a facially neutral statute when there was evidence of a malfunction). Opponents of the doctrine claim that facially neutral statutes, even if enacted for permissible purposes, can nonetheless impinge on the religious freedom of individuals. See, for example, Michael W. McConnell, Free Exercise Revisionism and the Smith Decision, 57 U Chi L Rev 1109, 1133-34 (1990) (arguing that a statute that punished refusal to be sworn violated religious freedom as applied to a Jewish witness who refused to be sworn on Saturday).

90 See Laurence H. Tribe, American Constitutional Law 789-94 (Foundation 2d ed 1988) (labeling cases reviewing regulations intended to affect the conveyance of messages as "track one" cases, and those reviewing regulations that have only unintended effects on expression as "track two" cases). See also Alexander, 44 Hastings L J at 921-27 (cited in note 60). 
that, whatever the motive of those who wrote the rules, when they were applied to him, they reduced his freedom of speech.

We have already seen why this approach has fallen into disfavor." All legal rules reduce the freedom of some people in order to expand the freedom of others. A court that set out to maximize overall freedom would make all government decisions either mandatory or impermissible. At least in part for this reason, the formal conception has become dominant. On this view, the question is not whether individual litigants have more or less freedom but whether there is evidence of government malfunction.

The main evidence that has concerned the Court is nonneutrality, which can manifest itself either through facial discrimination or discriminatory intent. Nonneutrality is facial when a statute or policy by its own terms differentiates between groups in a constitutionally problematic fashion. ${ }^{2}$ Discriminatory intent is present when the statute or policy, even though facially neutral, is written in order to achieve a constitutionally problematic outcome. ${ }^{93}$ It bears emphasis that in either case, what is important is not the actual effect of the statute on the freedom of the individuals before the court but the evidence the statute provides of government malfunction.

How does this distinction play out in the free speech context? An advocate of the as-applied approach would ask whether the statute in question had the effect in a particular case of reducing freedom that the Constitution protects. Thus, any application of a statute that prevented a person from expressing herself would be constitutionally suspect. Based on this approach, for example, the trespass statute in Marsh would pose a serious constitutional issue because of the statute's effect on Marsh's ability to convey his message. Similarly, a failure to enact the New Jersey antidiscrimination law might be constitutionally suspect because it might diminish Dale's ability to make his point about gay rights.

In contrast, the formal approach focuses on the nature of government intervention. The Court has created a byzantine body of doctrine relating to content neutrality, subject matter neutrality, and viewpoint neutrality to distinguish between permissible and suspect

91 See Part I.B.

92 See, for example, Johnson $v$ California, 543 US 499, 506 (2005) (remanding for strict scrutiny review of a prison policy that facially segregated prisoners by race).

93 See, for example, Hunter v Underwood, 471 US 222, 231-33 (1985) (invalidating a statute that prohibited people convicted of crimes of moral turpitude from voting because the statute, although facially neutral, was racially motivated). 
interventions. Without parsing this doctrine here, ${ }^{44}$ we can see the main point through a single example.

Consider again the problem of flag burning. Despite its critics' claims to the contrary, the Court has never held that there is a constitutional right to burn an American flag, at least if by "constitutional right" one means that individuals have immunity from punishment when they engage in this conduct. Under a properly drawn statute that exhibited no evidence of malfunction -for example, a statute that generally prohibited setting fires in public places - a flag burner could indeed be punished even if the punishment prevented him from expressing a point of view." A problem has arisen only because flag burning statutes have not been properly written or motivated. They have been nonneutral, either because on their face they have made punishment turn on the message conveyed by the burning or because they have been written with the intent to discourage certain messages.

For the most part, modern constitutional law reflects the victory of the formal approach. For example, in Washington v Davis, the Court held that "neutral" statutes are subject to only rational basis review even if they have a disproportionate adverse effect on racial minorities. ${ }^{97}$ Similarly, a government decision not to fund abortions does not violate the Due Process Clause even if, on the individual level, the failure to fund makes it impossible for poor women to exercise reproductive choice. ${ }^{98}$ Facially neutral statutes that severely impinge on an individual's religious activities do not violate the Free Exercise Clause." And, as the flag burning example illustrates, in general the Court has been unsympathetic to free speech claims that arise incidentally from even-handed, content-neutral regulation that is not motivated by the desire to suppress speech. ${ }^{100}$

94 For good, if now somewhat dated, summaries, see Tribe, American Constitutional Law at 977-97 (cited in note 90); Geoffrey R. Stone, Content Regulation and the First Amendment, 25 Wm \& Mary L Rev 189 (1983); Geoffrey R. Stone, Restrictions of Speech Because of Its Content: The Peculiar Case of Subject-matter Restrictions, 46 U Chi L Rev 81 (1978).

95 In Texas $v$ Johnson, the Court invalidated Johnson's conviction for flag burning only because the state had failed to assert "an interest in support of Johnson's conviction that [was] unrelated to the suppression of expression." 491 US at 407. Similarly, in Eichman, the Court invalidated the Flag Protection Act of 1989 because even though the Act contained no explicit content-based limitation on the scope of prohibited conduct, it was nonetheless clear that the government's interest was related to the suppression of speech. See $496 \mathrm{US}$ at 315-16.

96426 US 229 (1976).

97 Id at 242.

98 See Maher v Roe, 432 US 464, 470-71 (1977); Harris v McRae, 448 US 297, 316 (1980).

99 See Oregon v Smith, 494 US at 890 (upholding a statute prohibiting the use of peyote).

100 See, for example, Arcara v Cloud Books, Inc, 478 US 697, 702-05 (1986) (upholding the closure of an adult bookstore where the bookstore facilitated prostitution); O'Brien, 391 US at 376-77 (upholding a statute prohibiting the destruction of draft cards). But see Part III.B. 
Dale stands in sharp contrast to this general trend. As many critics of the decision have pointed out, ${ }^{101}$ the New Jersey antidiscrimination law was a facially neutral measure unrelated to speech. It was motivated by the desire to suppress discrimination, not a desire to inhibit any message BSA wished to convey. Under standard First Amendment doctrine, then, the Court should have applied only low-level scrutiny to it. Moreover, on this theory, Dale could be overruled without jeopardizing decisions like Tornillo, Texas $v$ Johnson, or Hague. Unlike the Dale statute, the Tornillo "right-of-reply" statute was content-based in the sense that the right to reply was triggered by the content of the newspaper's speech. Although a hypothetical shift in the property interests in flags might be facially neutral, it would almost certainly be motivated by the purpose of discouraging the political message conveyed by flag desecration. As we shall see, ${ }^{102}$ the Hague problem is more complex, but at least some of the "public forum" law growing out of Hague rests on requirements of content neutrality and permissible motivation. ${ }^{103}$

Thus, critics of Dale may be justified in their outrage at the Court's inconsistency. They should nonetheless be careful what they wish for. Some of these same critics regularly castigate the Court for its more general adherence to a formal conception of constitutional law. ${ }^{104}$ With some justification, they have claimed that constitutional rights lose much of their force when the Court ignores the adverse effects that "neutral" government policies have on their exercise. Poor women hardly have a "right" to an abortion when they have no money to pay for them, and African-Americans are hardly free of discrimination when "neutral" standards and tests exclude them from positions of power and influence. Perhaps, then, the Dale Court can be chastised for hypocrisy, having failed to apply its usual deference to a facially neutral law that had the effect of protecting the rights of gay men and lesbians, but the Court's liberal critics are also flirting with hypocrisy. It will take some work to explain how both Dale and Davis can be overruled.

Moreover, even people who are generally sympathetic to the formal approach are bound to have reservations about a complete victory for it. True, the particular statute in Tornillo was not content-

101 See, for example, Clark, $76 \mathrm{~S}$ Cal L Rev at 557 (cited in note 51).

102 See Part III.B.4.

103 See, for example, Lamb's Chapel v Center Moriches Union Free School District, 508 US 384, 394-97 (1993) (invaliding a rule that permitted after-school use of school property except for religious purposes on the ground that the restriction was viewpoint-based).

104 Compare, for example, Cass R. Sunstein, Tilting the Scales Rightward, NY Times A23 (Apr 26, 2001) (citing Dale as evidence that "[w]e are now in the midst of a remarkable period of right-wing judicial activism"), with Sunstein, 87 Colum L Rev at 875 (cited in note 20) (criticizing Davis for adopting Lochner-like understandings of government inaction and neutrality). 
neutral, but it is easy to imagine a similar statute that might be. Suppose that the government simply nationalized all newspapers, without regard to their content, as part of a broader nationalization of major industries. Or imagine that the government, without regard to content, simply prohibited speech in all public spaces, thereby leaving those without their own property no place at all where they could express their opinions. ${ }^{105}$

Indeed, the very distinction between the formal and the as-applied approach is fragile and perhaps unsustainable. As many critics of Davis have pointed out, ${ }^{106}$ government indifference to the impact of its programs on constitutional values is, itself, a kind of malfunction. And even if indifference were not constitutionally problematic, the tools the Court has developed to detect government malfunction are insufficiently sensitive. For example, rules that have adverse effects on speech but that are not content-based may nonetheless evidence government malfunction if government officials are willing to suppress some speech of which they approve in order to outlaw speech of which they disapprove. And more generally (and radically), background principles of property and contract may reflect a tolerance for constricted speech opportunities that is so pervasive it is not even noticed. ${ }^{107}$

\section{E. Where This Leaves Us}

The upshot of this analysis is that we are confronted with two overlapping dilemmas. The first dilemma emphasizes the conflict between the modern Court's rejection of Lochner and Marsh on the one hand and its acceptance of civil liberties on the other. We could protect civil liberties by making prepolitical property distributions either mandatory or impermissible, but if we insist on leaving these distributions in the discretionary political sphere, then we cannot also place civil liberties in the mandatory sphere.

The formal rights approach suggests an escape from this dilemma but only at the price of creating another one. This approach leaves property in the discretionary sphere but only so long as redistribution does not exhibit government malfunction (here defined as a reallocation that is facially related to speech or that is motivated by speechrelated reasons). The upshot is that this approach provides some space

105 Even some conservatives, who are generally hostile to constitutional protection for positive conceptions of liberty, find this outcome constitutionally troubling. See, for example, Charles Fried, Modern Liberty and the Limits of Government 105 (Norton 2007).

106 See, for example, David A. Strauss, Discriminatory Intent and the Taming of Brown, $56 \mathrm{U}$ Chi L Rev 935, 938 (1989) (arguing that "when the discriminatory intent standard is applied rigorously, it defeats itself").

107 See Part IV.B. 
for civil liberties without constitutionalizing everything. On this theory, Dale could be overruled (because the antidiscrimination statute is unrelated to speech) without jeopardizing Tornillo, Texas $v$ Johnson, and some aspects of Hague (because in each of these cases the reallocation of property rights is related to speech).

The problem, though, is that formal constitutionalism significantly waters down speech rights. Facially neutral and properly motivated laws may nonetheless have a dramatically negative incidental impact on individual freedoms. Conversely, nonneutral laws that reallocate property rights so as to achieve speech objectives, which are unconstitutional under the formal approach, may in fact increase speech opportunities. One can avoid arid formalism, but this solution also comes at the price of constitutionalizing the entire social sphere. It is worth emphasizing again that every allocation of every property right affects who speaks and what they say. Applied rights are therefore as much in tension with maintaining room for discretionary politics as the old Lochner regime.

More importantly, according to at least one standard account of free speech, an as-applied regime is deeply inconsistent with fundamental First Amendment premises. On this view, political speech is important precisely because politics is important. Speech is the means by which we implement the goal of community self-governance. ${ }^{108}$ But community self-governance presupposes the existence of a discretionary political sphere. If all allocations are mandatory, there remains nothing to speak about.

The upshot, then, is that if we are to have free speech rights immune from political interference, they must be grounded in either a formal property regime (Lochner), a formal rights regime (Tornillo, Texas $v$ Johnson, and some aspects of Hague), or a thoroughly constitutionalized and depoliticized social sphere (Marsh). There is no obvious escape from this trilemma, and so it is hardly surprising that First Amendment law is a mess. The next Parts survey the unpretty landscape.

108 For the best-known articulation of this point, see Alexander Meiklejohn, Free Speech and Its Relation to Self-Government 61-63 (Harper 1948). 


\section{DISCRETIONARY PROPERTY REGIMES AND THE COLLAPSE OF FREE SPEECH}

\section{A. The Marginalization of Marsh and Lochner}

The story of the repudiation of Lochner is exceedingly well known $^{109}$ and need not be repeated here. What is less well understood is the link between that repudiation and the discrediting of Marsh. In one sense, Marsh and Lochner are located at opposite poles. Whereas Marsh makes supposedly prepolitical property distributions impermissible, Lochner makes them mandatory. Yet in another sense, the cases are cousins: both provide a grounding for constitutionally mandatory speech rights by constitutionalizing property rights. It is not a surprise then that, as the Court has dismantled Marsh, it has sometimes relied on earlier cases attacking Lochner.

Forty years ago, the Court flirted with the notion of expanding Marsh by constitutionalizing state trespass laws in the context of the sit-in movement to desegregate southern public accommodations. ${ }^{110}$ In retrospect, perhaps the most significant fact about this episode is that the Court resisted the temptation to do so. It awkwardly managed to reverse each of the sit-in convictions that reached it without deciding the ultimate constitutional question."

The most significant opinion opposing constitutionalization was a dissent written by Justice Black, the author of Marsh and Roosevelt's first appointee to the Court. ${ }^{12}$ Given what he had said in Marsh, it is perhaps surprising that Justice Black's opinion in the sit-in case expressly tied free speech rights to property right entitlements. ${ }^{113} \mathrm{He}$ emphasized that the right of sit-in demonstrators to express their point of

109 See, for example, Bruce Ackerman, 2 We The People: Transformations 280 (Belknap 1998) (arguing that Lochner was repudiated because the country moved away from Reconstruction Republican values, not because the Lochner Court was out of line with those values); Robert G. McCloskey, The American Supreme Court 117-26 (Chicago 4th ed 2005) (describing the Court-packing plan and the Court's 1937 change in direction that took economic policies out of the realm of review for "reasonableness").

110 See, for example, Barr v City of Columbia, 378 US 146, 149 (1964).

111 See id (reversing for insufficient evidence a sit-in demonstrator's conviction for breach of the peace); Bouie v City of Columbia, 378 US 347, 357-58 (1964) (noting the difference between civil and criminal trespass and holding that demonstrators could not be convicted of criminal trespass without an actual breach of the peace); Hamm v City of Rock Hill, 379 US 306, 317 (1964) (holding that the Civil Rights Act of 1964 prohibits prosecution of sit-in demonstrators for trespassing); Bell v Maryland, 378 US 226, 236 (1964).

112 See Bell, 378 US at 319 (Black dissenting).

113 Justice Black argued that "[t]he right to freedom of expression is a right to express viewsnot a right to force other people to supply a platform or a pulpit" and that "[t]he experience of ages points to the inexorable fact that people are frequently stirred to violence when property which the law recognizes as theirs is forcibly invaded or occupied by others." Id at 345-46. 
view depended upon their having a property interest in the place where that view was expressed. Whereas in Marsh he endorsed a constitutionally mandated shift of property entitlements to facilitate speech, in the sit-in context he emphasized that property rights were in the discretionary sphere. While legislatures were free to make the shift (a point he emphasized a year later by joining the Court's opinions upholding the public accommodations sections of the 1964 Civil Rights Act ${ }^{14}$ ), the Court acting under constitutional compulsion was not. Significantly, Justice Black's opinion relies for this proposition on Nebbia $v$ New York, ${ }^{115}$ perhaps the earliest Supreme Court case rejecting Lochnerlike line drawing that relegated some government market regulations to the impermissible sphere.

During the 1970s, the Court briefly experimented with a more modest expansion of Marsh, extending its application to picketing activity at privately owned shopping centers. After initially extending Marsh to apply to this situation, ${ }^{117}$ it quickly reversed course. ${ }^{118}$ Once again, the Court held that shifts in property rights were constitutionally discretionary rather than mandatory. Thus, while upholding a statute that obligated shopping malls to permit picketing, it also held that the Constitution of its own force did not require this result. ${ }^{119}$ And once again, the Court linked its repudiation of Marsh-like redistributive rights to a discrediting of Lochner-like constitutional protections for existing distributions. As then-Justice Rehnquist wrote in the course of upholding a statute requiring access to shopping centers for speech activity, "It is ... well established that a State in the exercise of its police power may adopt reasonable restrictions on private property so long as the restrictions do not amount to a taking without just compensation or contravene any other federal constitutional provision."

114 See Heart of Atlanta Motel v United States, 379 US 241, 268 (1964) (Black concurring). See also Bell, 378 US at 318 (Black dissenting) (emphasizing that the case "does not involve the constitutionality of any existing or proposed state or federal legislation requiring restaurant owners to serve people without regard to color").

115291 US 502 (1934).

116 See Bell, 378 US at 341 n 37 (Black dissenting) (citing Nebbia for the proposition that "this Court some years ago rejected the notion that a State must depend upon some rationalization such as 'affected with a public interest' in order for legislatures to regulate private businesses").

117 See Amalgamated Food Employees Union Local 590 v Logan Valley Plaza, Inc, 391 US $308,317-18$ (1968) (finding that a shopping center was functionally equivalent to the privately owned business district in Marsh for First Amendment purposes), overruled by Hudgens $v$ $N L R B, 424$ US 507,518 (1976).

118 See Lloyd Corp v Tanner, 407 US 551, 559-61 (1972) (limiting Logan Valley); Hudgens, 424 US at 518 (overruling Logan Valley).

119 See PruneYard Shopping Center v Robins, 447 US 74, 88 (1980).

120 Id at 81 . 
More broadly, the Court has sharply constrained the reach of the constitutional theory under which Marsh was decided. The Marsh theory was that if the government delegated a "public function" to a private entity, the government was responsible when that entity took action that impinged on constitutional values. What made something a "public function"? The Court's decisions suggested two possibilities. A private entity might be engaged in a public function when it is able to exert extraordinary coercive power comparable to state power over individuals. ${ }^{121}$ Alternatively, an entity might be engaged in a "public function" when it voluntarily opens itself to the public in a fashion that made its claims to immunity from government regulation implausible. ${ }^{122}$

In the more recent cases, the presence of neither factor has been sufficient to trigger the public function doctrine. For example, in Jackson v Metropolitan Edison $\mathrm{Co}^{123}$ the Court held that a privately owned public utility was not engaged in a public function even though, under modern conditions, its ability to terminate electric service gave it extraordinary power over individuals and even though its business was generally open to the public. ${ }^{124}$ It bears emphasis that the Court's announcement of these principles yet again coupled the discrediting of Marsh with a quotation from Nebbia, where the earlier Court had distanced itself from Lochner. ${ }^{125}$

Similarly, in Flagg Brothers $v$ Brooks, ${ }^{126}$ another case rejecting the public function doctrine, the Court emphasized in post-Lochner fashion the discretionary character of property rights. Then-Justice Rehnquist, once again writing for the majority, insisted that a "property interest is not a monolithic, abstract concept hovering in the legal stratosphere. It

121 See, for example, Terry $v$ Adams, 345 US 461, 469 (1953) (striking down a racially restrictive primary by a "private organization" on the ground that it was "[t]he only election that has counted in this Texas county for more than fifty years").

122 See, for example, Evans $v$ Newton, 382 US 296, 301 (1966) (finding that the service rendered by a private park was "municipal in nature" because "[the park] is open to every white person, there being no selective element other than race").

123419 US 345 (1974).

124 Id at 351-52.

125 The Jackson Court explained:

[As we] stated long ago ... in the course of rejecting a substantive due process attack on state legislation: It is clear that there is no closed class or category of businesses affected with a public interest .... The phrase "affected with a public interest" can, in the nature of things, mean no more than that an industry, for adequate reason, is subject to control for the public good. In several of the decisions of this court wherein the expressions "affected with a public interest" and "clothed with a public use," have been brought forward as the criteria ... it has been admitted that they are not susceptible of definition and form an unsatisfactory test.

Id at 353, quoting Nebbia, 291 US at 536.

126436 US 149, 161 (1978). 
is a bundle of rights in personalty, the metes and bounds of which are determined by the decisional and statutory law of the State." ${ }^{127}$

\section{B. Free Speech in a World of Discretionary Property Entitlements}

As the preceding discussion illustrates, the post-New Deal compromise holds that the protection of existing property distributions is neither mandatory nor impermissible. The twin rejections of Lochner and Marsh are linked by a commitment to the discretionary political sphere.

What, though, are we to make of free speech rights in this environment? The New Deal compromise places laws impinging on these rights in the impermissible sphere, but the cases make plain that this categorization is, to say the least, unstable. When property rights are discretionary, free speech rights tend to become discretionary as well.

One can think about this erosion in two different ways. One might view the destabilization of free speech rights as simply the consequence of the demise of Lochner and Marsh. It turns out, though, that the relationship between Lochner and free speech rights is more complex than might first appear. The problem is that the cultural power of free speech rights is strong enough to make total abandonment of the First Amendment an unsatisfactory outcome. There is a need, therefore, to cabin the erosive force of a discretionary property regime. A second way to see the cases, then, is that even as it rejects Lochner, the Court is sometimes forced into line drawing that is strongly reminiscent of the Lochner era. Despite the disclaimer in Nebbia, now as during the Lochner era, the Court finds itself caught up in the slotting of cases into natural categories-those involving activity "affected with the public interest" and therefore within the police power on the one hand, and those that are located in the private sphere of freedom on the other.

The cases where the Court finds speech rights discretionary therefore present an odd mix of Lochner and post-Lochner reasoning. Whichever technique the Court uses, however, the outcome is the same. Either prepolitical property distributions are treated as completely discretionary, or the Court attempts to draw a line between discretionary and mandatory distribution. Whichever choice it makes, free speech rights never survive placement of property rights in the discretionary category. This Part canvasses cases illustrating this proposition. The next Part examines cases where the Court has attempted to fix property rights and, with them, free speech protections. 
1. Broadcast regulation.

Consider first government regulation of broadcasters. In the well known case of Red Lion Broadcasting Co v FCC, ${ }^{128}$ the Court upheld the FCC fairness doctrine and personal attack rule, which under some circumstances required license holders to broadcast speech that they opposed.

Red Lion is in obvious tension with Tornillo, where the Court invalidated a "right-of-reply" statute in the context of print media. More significant for our purposes, however, is the precise parallel between the Red Lion problem and the Dale problem. In both cases, one entity (Red Lion or BSA) "owns" property (a television license or the Boy Scouts), and in both cases the government provides someone else (someone taking advantage of the fairness doctrine or Dale) access to the property so that the nonowner can engage in expressive activity opposed by the owner. But whereas in Dale, the Court implicitly treats the original property allocation as fixed, the Red Lion Court emphasizes its discretionary character:

A license permits broadcasting, but the licensee has no constitutional right to be the one who holds the license or to monopolize a radio frequency to the exclusion of his fellow citizens. There is nothing in the First Amendment which prevents the Government from requiring a licensee to share his frequency with others and to conduct himself as a proxy or fiduciary with obligations to present those views and voices which are representative of his community and which would otherwise, by necessity, be barred from the airwaves.

It does not follow from this that reallocation of the property interest is constitutionally mandatory in Marsh-like fashion. In Columbia Broadcasting System, Inc v Democratic National Committee, ${ }^{130}$ the Court concluded that the Constitution by its own force did not prohibit a broadcaster's exclusion of competing views. ${ }^{131}$ Thus, in this area, neither Lochner nor Marsh has force.

What does follow is that, in a world without either Lochner or Marsh, the First Amendment protects the speech rights of neither the broadcaster nor the nonowner. Precisely because the government can shift the property entitlement ("the licensee has no constitutional right to be the one who holds the license"), the First Amendment right

\footnotetext{
128395 US 367 (1969).

129 Id at 389.

130412 US 94 (1973).

131 See id at 127.
} 
of the owner disappears ("[t]here is nothing in the First Amendment which prevents the government from requiring a licensee to share his frequency with others"). And precisely because background rules of property entitlement are not "state action," the nonowner, too, is left without speech rights.

Why is the property right fixed in Dale and discretionary in Red Lion? The Red Lion Court pointed to the fact of physical scarcity of the broadcast spectrum to justify regulatory intervention..$^{132}$ More recently, the Court has reemphasized this difference. In Turner Broadcasting System, Inc v FCC, ${ }^{133}$ the Court considered a First Amendment challenge to a statute requiring cable companies to carry the signals of local, over-the-air broadcasters. Although it ultimately upheld the statute, it did so despite finding that the Red Lion rationale was inapplicable to cable television, which is not burdened by the spectrum limitations of broadcast television. ${ }^{134}$

As many others have pointed out, ${ }^{135}$ it is harder to restrict application of the scarcity theory than the Court supposes. After all, market pricing is always based on the fact that the resources bought and sold are scarce. It has less often been noticed that not as much turns on the scarcity rationale as one might suppose from the Court's rhetoric. In Turner, for example, although the Court brings out the heavy machinery of First Amendment analysis to determine whether the statute violates free speech rights, it is not clear how much work this machinery actually does. When the dust settles, after a lengthy discussion of levels of scrutiny, content neutrality, and narrow tailoring, the Court once again upholds the statute granting access, thereby treating the property interest as discretionary. Similarly, the Court has specifically disclaimed a distinction based on spectrum scarcity in the course of upholding in the cable context some restrictions on indecent speech. ${ }^{136}$

It should be noted as well that even in the absence of spectrum scarcity, the Court has sometimes used a rationale for regulation that closely parallels the Red Lion argument. Thus, in Turner, the Court

132 See 395 US at $396-401$.

133512 US 622 (1994).

134 See id at 638-39.

135 See, for example, Lucas Powe, American Broadcasting and the First Amendment 197-209 (California 1987) (criticizing the scarcity justification for restricting broadcaster speech, and stating that "[i]t is not technological scarcity that is at work, but lack of a property mechanism to allocate the right to broadcast"); R.H. Coase, The Federal Communications Commission, $2 \mathrm{~J}$ L \& Econ 1, 12-27 (1959) (arguing that scarcity is present in nearly all resources and that we generally trust prices to properly control the scarcity problem).

136 See Denver Area Educational Telecommunications Consortium, Inc v FCC, 518 US 727, 748 (1996) (noting that cable and over-the-air broadcasting differ little with regard to the problem of exposure of children to "offensive" programming). 
ended up crediting government concerns about the monopoly power exercised by cable operators, ${ }^{137}$ much as it worried about the exclusive control of the limited broadcast spectrum by over-the-air broadcasters.

If scarcity does not explain the distinction between Dale and Red Lion, what does? I will have more to say about this question in Part IV. For now, it is enough to note that the problem is a familiar one. In an earlier generation, the Lochner-era Court faced similarly skeptical questions about the distinction between permissible and impermissible government regulation. In his Lochner dissent, for example, Justice John Harlan pressed the majority on the distinction between bakers (who could not be subject to legislation setting maximum hours) and miners (who could be)..$^{138}$ Defenders of the Court's modern jurisprudence face a similar problem in distinguishing between broadcasters and Boy Scouts.

Turner and Red Lion illustrate the reemergence of this sort of line-drawing despite the Court's supposed abandonment of it in cases like Nebbia. Here, as in the pre-Nebbia days, the Court is, in effect, making a distinction between businesses "affected by the public interest" and therefore subject to regulation under the police power, and "ordinary" businesses with fixed property rights. Television broadcasters, whether cable or over-the-air, like innkeepers and common carriers of old, are subject to regulation, while the Boy Scouts, like "ordinary businesses," are not. It turns out, in other words, that there is indeed a "closed category" of businesses affected with the public interest that are appropriately subject to government regulation. Much as during the Lochner era, the boundaries are treated as forming a natural category apparently defined by some version of market failure derived from a contestable economic theory adopted by the Court. And, it turns out, only businesses lucky enough to stay outside of the closed category have First Amendment protection.

\section{2. "New" property and freedom of speech.}

One explanation for the different treatment of broadcasters is that the property at stake seems to derive from the very regulation being challenged. Unlike "old" or "natural" property, it is claimed, broadcast licenses exist only because the government created them. Because the property is the creation of the government, its allocation is necessarily

137512 US at 632-34.

138 Writing for the majority, Justice Rufus Peckham distinguished Holden v Hardy, 169 US 366 (1898), which had upheld maximum hours legislation for mine workers. Jutsice Peckham wrote that "the kind of employment" was such as to make the legislation "reasonable and proper." Lochner, 198 US at 54. Justice Harlan's dissenting opinion responded by arguing that there was no meaningful distinction between baking and mining. See id at 71-72. 
discretionary. It seems to follow-or at least sometimes it seems to follow - that the government can condition the grant of the property right on a relinquishment of free speech claims.

Reasoning of this kind has a special place in the history of Lochner's decline. At the very close of the Lochner era, the Court decided United States $v$ Butler, ${ }^{139}$ which invalidated an important New Deal agricultural program on the theory that the conditioning of grants to farmers on their curtailment of production coerced the curtailment, thereby invading the reserved power of the states. ${ }^{140}$ Justice Owen Roberts's opinion for the Court has been widely derided, but it is strikingly modern in its recognition that the failure to provide a benefit can be just as coercive as the imposition of a burden. Agricultural subsidies, like broadcast licenses, seem to be "new property" created by the state. Yet Justice Roberts recognized that the conditional withholding of this property might nonetheless jeopardize constitutional values. ${ }^{1.14}$

The legacy of Butler is deeply ironic. For the Butler Court's conservative majority, the isomorphism of imposing burdens and withholding benefits provided an argument for the constitutionalization of boundaries between state and federal power. In different hands, however, the Butler insight can easily give rise to Marsh-like rights. After all, if the withholding of a benefit counts as coercion, then publicly imposed coercion is implicated in all private arrangements because there is always some sort of failure to subsidize alternative arrangements. All such arrangements are therefore subject to constitutional challenge and to judicially imposed reallocations in order to further constitutional values. Broad-based constitutionalization of this sort threatened the part of the New Deal compromise that left ordinary social and economic legislation in the discretionary sphere. It therefore became necessary to reestablish some sort of distinction between the imposition of burdens and the withholding of benefits.

The Court's effort to maintain this distinction has been famously unsuccessful. ${ }^{1.2}$ For present purposes it is enough to notice that when the Court insists on the distinction, it makes the property interests created by government subsidies discretionary, and that, once the property interest is slotted in this category, free speech claims disappear.

139297 US 1 (1936).

140 Id at $67-72$.

141 See id at 72.

142 For criticisms of the doctrine, see Cass R. Sunstein, Why the Unconstitutional Conditions Doctrine Is an Anachronism, 70 BU L Rev 593, 601-02 (1990); Kathleen M. Sullivan, Unconstitutional Conditions, 102 Harv L Rev 1413, 1416-17 (1989); Richard A. Epstein, Foreword: Unconstitutional Conditions, State Power, and the Limits of Consent, 102 Harv L Rev 4,11-12 (1988). 
Consider, for example, Rust $v$ Sullivan..$^{133}$ A federal regulation prohibited private entities receiving public funds from encouraging the use of abortion as a method of family planning. An organization receiving such funds claimed that its First Amendment rights were violated, but the Court rejected its claim. According to the Court, the government had "not denied [the organization] the right to engage in abortion-related activities. Congress has merely refused to fund such activities out of the public fisc.",

The reasoning here is familiar and is rooted in Proposition 3 (establishing that freedom of speech does not include the right to use another's property). Family planning organizations have the right to use their own property to advocate abortions, but not the government's property. The money they receive from federal grants is the government's property because the government has the discretion to spend. It has this discretion, in turn, because it has no affirmative obligation to provide benefits in order to facilitate abortions. Since the property right is discretionary, it follows that the government can condition use of the property on relinquishment of speech rights.

There are well known difficulties with this line of argument, however. Recall that one half of the New Deal compromise involved shifting even "natural" property rights into the discretionary sphere. ${ }^{145}$ An important part of the theoretical foundation for doing so was a destabilization of the burden/benefit distinction. Ultimately, the distinction must rest on the difference between upward and downward departures from a fixed baseline. ${ }^{146}$ At one time, natural law concepts established such a baseline, but the New Deal compromise entailed giving up on these concepts as limits on government action. Because the New Deal compromise also rejected constitutionalization of the entire social sphere-a necessary consequence of treating the withholding of a benefit as equivalent to a burden - the various branches of the compromise lead to contradictory results.

The upshot is that sometimes the modern court rejects free speech rights when dealing with "new" property, and sometimes it does not. There is no need to go through the various doctrinal gyrations the Court has deployed in its attempt to make sense of this contradiction.

143500 US 173 (1991).

144 Id at 198.

145 See text accompanying notes 25-27.

146 Consider Seth F. Kreimer, Allocational Sanctions: The Problem of Negative Rights in a Positive State, 132 U Pa L Rev 1293, 1324-26 (1984) (discussing the difficulty of theoretically distinguishing action from inaction); Robert Nozick, Coercion, in Sidney Morgenbesser, Patrick Suppes, and Morton White, eds, Philosophy, Science, and Method 440, 447-49 (St Martin's 1969) (arguing that whether something is classified as a "threat" or an "offer" depends on how it affects a baseline "normal course of events"). 
For present purposes, it is enough to note that on some occasions, even when it appears that the Court has fixed the property right, and so seemingly paved the way for First Amendment protection, it has actually left both speech and property in the discretionary category.

For example, compare Rust with Rosenberger $v$ Rector and Visitors of the University of Virginia. ${ }^{147}$ The University of Virginia administered a "student activities fund" that paid for the costs of student publications. However, the University prohibited payments to any publication that "primarily promotes or manifests a particular belief in or about a deity or an ultimate reality." $A$ group of students publishing a Christian magazine challenged the limitation.

Given Rust, one might have supposed that the challenge would fail. Here, as in Rust, the group was claiming the right to use the state's money, rather than its own. The Court distinguished Rust, however, and, in this context, upheld the free speech claim. According to the Rosenberger Court's retrospective reconstruction, Rust stood for the proposition that "the government [is permitted to] regulate the content of what is or is not expressed when it is the speaker or when it enlists private entities to convey its own message." ${ }^{149}$ In contrast, Rosenberger involved a case where the government was "not itself speak[ing] or subsi$\mathrm{diz}$ [ing] transmittal of a message it favors but instead expend[ing] funds to encourage a diversity of views from private speakers. ${ }^{1,150}$

Does this distinction make sense? There is less here than meets the eye. It is easy to recharacterize the Rust program as the provision of money to facilitate private choice. Conversely, the very limitations on the use of funds invalidated in Rosenberger might have been taken as evidence that the government meant to finance its own secular message.

This ease of recharacterization, in turn, suggests that the Rosenberger Court has not really fixed the property right. Rosenberger maintains, rather than destroys, government discretion either to keep the money itself and use it to promote its own message or to give it to private individuals who can use it for whatever message they desire. True, when the government exercises that discretion in favor of distribution to private individuals, those individuals have free speech rights. The point of Rust, though, is that this choice is not constitutionally compelled. The government might instead keep the money and use it for its own purposes. When it does so, even if it uses private individuals to achieve those purposes, free speech rights disappear. The government

147515 US 819 (1995).

148 Id at 822-23.

149 Id at 833.

150 Id at 834 . 
discretion to keep or dispose of its own property therefore morphs into government discretion to allow or forbid speech.

3. "Old" property and private fora.

As the previous section indicates, part of the New Deal compromise depends on maintaining a distinction between "new" property (the result of the provision of government benefits) and "old" property (that somehow exists prior to government). The discretionary character of new property is more readily apparent and free speech rights are therefore more fragile in this environment. But because another part of the New Deal approach involved placing even old property rights in the discretionary category, First Amendment claims sometimes seem fragile in this environment as well.

Comparing the outcome in three cases-Members of the City Council of the City of Los Angeles $v$ Taxpayers for Vincent ${ }^{151}$ City of Ladue $v$ Gilleo, ${ }^{152}$ and United States Postal Service $v$ Council of Greenburgh Civic Associations ${ }^{153}$-demonstrates the problem.

In Taxpayers for Vincent the Court upheld an ordinance that prohibited the posting of signs on public property. There is a limited First Amendment right of access to such property when the property in question is a "traditional public forum." "However, the Taxpayers for Vincent Court concluded that lamp poles and other kinds of public property where signs are posted did not constitute public fora. ${ }^{155}$ Once this determination was made, it followed that those posting signs were using someone else's property, rather than their own, in order to communicate their message. Of course, the First Amendment gives them no right to commandeer property in this fashion. The Court brought the point home by rejecting an argument that the city's putative aesthetic interest in prohibiting the signs was impeached by the fact that the ordinance permitted signs on private property. In the Court's view, the use of one's own property to communicate a message was fundamentally different from the use of public property. ${ }^{156}$

This distinction between the use of one's own and someone else's property is sharpened in Gilleo, where the Court distinguished Taxpayers for Vincent and struck down an ordinance prohibiting the posting of most signs on one's own property. Significantly, the "special re-

\footnotetext{
151466 US 789 (1984).

152512 US 43 (1994).

153453 US 917 (1981).

154 See Part III.B.4.

155 See 466 US at 814-15.

156 Id at $810-12$.
} 
spect for individual liberty in the home"157 was strong enough to invalidate the ordinance on an "as-applied" theory even on the assumption that it satisfied the formal demands of content neutrality. ${ }^{158}$ The Court thought that even if the restriction was content-neutral and, in this sense, did not manifest government malfunction, it nonetheless "unduly constrict[ed] the opportunities for free expression."159

Taken together, Taxpayers for Vincent and Gilleo make clear yet again that First Amendment rights turn on property entitlements. When the property does not belong to the speaker, she has no First Amendment rights, but if the speaker is using her own property, she has at least a prima facie free speech claim. However, this analysis assumes that the property entitlement is fixed and not subject to reallocation. A property entitlement in the window of one's own home (where Gilleo wanted to place his sign) might seem about as fixed as one can imagine, and indeed the Court did not pause to inquire whether the city could transfer ownership of the window.

Yet in a post-New Deal environment, even this entitlement is unstable. What are we to make, for example, of the City's claim that Gilleo's sign and others like it were reducing the property value of property owned by her neighbors? There is a sense in which Gilleo was using not just her property but her neighbor's as well to make her point. ${ }^{160}$ Nuisance law recognizes the competing property entitlement of surrounding landowners to prevent certain uses of property. The holding in Gilleo in effect makes nuisance law unconstitutional in this setting. The holding therefore amounts to a constitutionally mandatory shift of the property entitlement from the neighbors to Gilleo.

Might the entitlement be shifted in the other direction? Consider Greenburgh Civic Associations. There, as discussed above, the Court rejected a First Amendment challenge to a federal statute that, with certain exceptions, prohibited depositing unstamped "mailable matter" into letterboxes in private homes. ${ }^{161}$ Why is the private mailbox in Greenburgh Civic Associations different from the private window in Gilleo? One might suppose that the distinction lies in the fact that Gilleo was using her own window for her sign, whereas the Greenburg Civic Associations were placing leaflets in someone else's letterbox. But this distinction ignores the well-established First Amendment right of

157 Gilleo, 512 US at 58.

158 See id at 55.

159 Id at 55 n 13, quoting Geoffrey R. Stone, Content-neutral Restrictions, 54 U Chi L Rev 46,58 (1987).

160 On the interpenetration of property claims and nonexclusivity of property rights, see Carol M. Rose, Canons of Property Talk, or, Blackstone's Anxiety, 108 Yale L J 601, 621 (1998).

161 See notes 15-18 and accompanying text. 
individuals to receive, as well as to send, mail. ${ }^{162}$ As the dissent pointed out, a more narrowly tailored statute might have prohibited the placing of mailable matter in letterboxes only when the owner of the box indicated that he did not want the material. ${ }^{16}$

Remarkably, the majority in Greenburgh Civic Associations met this point by claiming that the letterbox did not in fact belong to the homeowner. Instead, the court insisted, this case fell within the category of cases like Taxpayers for Vincent where people were attempting to use "property owned or controlled by the government" for First Amendment purposes. On the majority's view,

[I]t is difficult to conceive of any reason why this Court should treat a letterbox differently for First Amendment access purposes than it has in the past treated [a] military base ..., [a] jail or prison, ... or [an] advertising space made available in city rapid transit cars .... In all these cases, this Court recognized that the First Amendment does not guarantee access to property simply because it is owned or controlled by the government. ${ }^{16}$

In one sense, the outcome of Greenburgh Civic Associations is quite surprising. Most of us do not think of a letterbox, erected by the homeowner and affixed to her property, as something "owned or controlled by the government." In another sense, however, the decision is completely unexceptional. What the rejection of Lochner means is that, if we put aside a few limiting cases, the government has the power to transfer property entitlements when doing so advances the public interest broadly conceived.

Greenburgh Civic Associations is startling only because it emphasizes what we have in some sense known all along: that when property transfers occur, they affect First Amendment entitlements. People have the right to use their own property, but not the property of others, to make their point. It follows that in the absence of constitutional principles making a property allocation either impermissible or mandatory, First Amendment rights become discretionary.

If such a transfer is unexceptional when dealing with a homeowner's letterbox, what about her window? There is no obvious way to distinguish between Gilleo and Greenburgh Civic Associations. It is true, for example, that the statute limiting access to letterboxes is content-neutral, but recall that the Gilleo Court held that the sign limitation was unconstitutional without regard to whether it was content-

162 See, for example, Lamont v Postmaster General, 381 US 301, 306-07 (1965).

163 See Greenburgh Civic Associations, 453 US at 152 (Stevens dissenting).

164 Id at 129. See also id at $131 \mathrm{n} 7$ ("What we hold is ... that property owned or controlled by the government which is not a public forum may be subject to a prohibition of speech."). 
based. Perhaps the government interest in regulation is stronger, or the First Amendment interest weaker, in Greenburgh Civic Associations than in Gilleo. Still, if we are to take seriously the claim that the letterbox or the window is not owned or controlled by the homeowner, the strength of the government interest and speech interest should be irrelevant. After all, Dale's First Amendment interest might be stronger than BSA's, but so long as the Boy Scouts "belong" to BSA, Dale has no First Amendment right to use its property to advance his speech interests.

What we are left with, then, are two modest points that support the distinction. First, as a matter of social fact if not logic, it simply makes more intuitive sense to think of the letterbox as under government control or ownership than to think of a home window as government property. Second, we need to hold onto this intuition because, without it, all speech rights become discretionary. It is precisely to avoid this fate that the Court sometimes ignores the first branch of the New Deal compromise and treats property rights as fixed so as to make speech rights fixed as well. The next Part provides some examples.

\section{CONSTITUTIONALLY MANDATORY AND IMPERMISSIBLE PROPERTY DISTRIBUTIONS}

\section{A. The Need for Fixed Entitlements}

The marginalization of Marsh and Lochner-and with it, the placement of property rights in the discretionary sphere-was necessary to protect one branch of the New Deal compromise, but it jeopardized the other branch. Property rights must be discretionary so as to allow for the wealth transfers at the heart of New Deal reforms, but if property rights are discretionary, how can speech rights be mandatory? Precisely because they cannot be, remnants of both Marsh and Lochner survive.

One need go no further than Dale itself to demonstrate this fact. As explained above, ${ }^{165}$ Dale can only be understood as a constitutionally mandated revision of background property rules thought necessary to vindicate First Amendment rights. Nor is Dale alone. We have already seen that even when the Court treats property rights-and, therefore, speech rights - as discretionary, it often does so against the backdrop of another class of cases, sometimes defined in a manner reminiscent of the Lochner era, where the rights are mandatory. ${ }^{166}$ This Part focuses on this other class of cases.

165 See Part I.B.

166 See Part II.B. 


\section{B. Some Examples}

For the most part, when the Court fixes property entitlements, it makes prepolitical property arrangements mandatory in the fashion of Lochner. Occasionally, however, it makes such arrangements impermissible in the fashion of Marsh. Either way, it fixes speech rights by fixing property rights as well. Some, but not all, of these cases can be domesticated as examples of formal constitutionalism. At least occasionally and sporadically, the Court continues to require either maintenance of prepolitical property distributions or property reallocations thought necessary to protect free speech. Some examples follow.

1. Trademark and copyright law.

Consider first San Francisco Arts \& Athletics, Inc v United States Olympic Committee. ${ }^{167}$ In general, the Lanham Act provides for trademark protection against unauthorized uses only when those uses are "likely ... to cause confusion, or to cause mistake, or to deceive." However, a special statutory provision allows the United States Olympic Committee (USOC) to control use of the word "Olympic" even in the absence of these conditions. ${ }^{169}$ The USOC sought relief against petitioners for promoting the "Gay Olympic Games," and petitioners responded by claiming that the statute violated their equal protection and free speech rights.

The Court rejected both these claims, but it did so in a puzzling fashion. With respect to the equal protection claim, the Court expressly disclaimed Marsh-style reasoning. Because background property rules were not "state action," it followed that USOC's decision to permit some but not other groups to use the word "Olympic" did not raise an equal protection issue. ${ }^{170}$ The Free Speech Clause, like the equal protection guarantee, can only be triggered by state action, so one would have thought that the equal protection holding would dispose of the free speech claim as well. Yet mysteriously, the Court responded to the free speech claim on the merits without resort to the "no state action" argument."

A careful reading of the section of the opinion dealing with the free speech claim suggests a reason for this difference in treatment. A rejection of Lochner- or Marsh-style state action means that the Constitution has nothing whatever to say about the impact of a private

\footnotetext{
167483 US 522 (1987).

168 See 15 USC $\$ 1052$ (d) (2006).

169 See 36 USC $\$ 220506$ (a)(4) (2006), previously codified at 36 USC $\$ 380$ (1988).

170 See San Francisco Arts, 483 US at 542-48.

171 See id at 532-41.
} 
individual's use of her property. The Court was willing to swallow this in the context of equal protection, but it was unwilling to do so in the First Amendment context. Thus, it carefully reserved the question "whether Congress ever could grant a private entity exclusive use of a generic word." On the Court's view, this case did not require it to confront this issue because here "Congress reasonably could conclude that the commercial and promotional value of the word 'Olympic' was the product of USOC's 'own talents and energy, the end result of much time, effort, and expense.","13 Apparently, it was only because "Congress reasonably could conclude that the USOC has distinguished the word 'Olympic' through its own efforts [that] Congress' decision to grant USOC a limited property right ... falls within the scope of trademark law protections, and thus certainly within constitutional bounds."

It would be overreading San Francisco Arts to insist that it contains a negative pregnant. The Court does no more than avoid a question it did not need to decide. Still, the desire to avoid the question was strong enough to generate a blatant and embarrassing inconsistency between its treatment of the equal protection and free speech claims. This inconsistency, in turn, at least suggests that the Court is unready to treat property allocations as completely discretionary when they severely impact speech opportunities.

It is easy to imagine hypotheticals that justify this reluctance. Suppose, for example, that Congress provided that only the Republican National Committee could use the expression "family values," or that only Democrats could speak of protecting people who "play by the rules." If one takes seriously an obligation to arrange property entitlements so as to create optimal speech opportunities, as Marsh requires, laws like these are intolerable. ${ }^{175}$ And lest one think that these examples are entirely hypothetical, a real dispute brings the point home: the Los Angeles Police Department recently attempted to sup-

172 Id at 532.

173 Id at 532-33, quoting Zacchini v Scripps-Howard Broadcasting Co, 433 US 562, 575 (1977).

174 San Francisco Arts, 483 US at 534-35.

175 Or at least they ought to be. The case law leaves the outcome of hypothetical examples like those discussed in the text in doubt. For example, in United We Stand America, Inc v United We Stand, America New York, Inc, 128 F3d 86, 93 (2d Cir 1997), the Second Circuit upheld against a First Amendment challenge the exclusive right of the $H$. Ross Perot campaign to use the phrase "United We Stand" in its title where use by another group might cause confusion. See also Birthright v Birthright, 827 F Supp 1114, 1135 (D NJ 1993) (ordering judgment for the plaintiff in a Lanham Act action against use of the term "birthright"). 
press movie and television shows critical of its performance by claiming that it had a property interest in use of the abbreviation "LAPD."176

Interestingly, however, the Court's emphasis was on property rights of the Lochner type, rather than the Marsh variety. The Court limited the scope of its holding on the ground that the Olympic Committee had invested the term "Olympics" with meaning "through its own efforts." The suggestion is that the property entitlement is not merely statutory in origin but stems from a prepolitical, Lockean natural right to the fruits of one's labor. This right is apparently not strong enough to move its recognition to the mandatory sphere (Congress did not have to give the Olympic committee statutory protection), but it is strong enough to keep it out of the impermissible sphere.

The Court's Lochner-style rhetoric, however, conceals a possibility, latent in its decision, of Marsh-style redistributions. What outcome would the Court reach in a case where there were not prepolitical Lochner-like property rights? Suppose, for example, that a statute gave the Kraft company the exclusive right to use the word "cheese." Because Kraft did not create the meaning of the word "cheese" through its "own efforts," the Court's reasoning suggests that the First Amendment would make existing property distributions unconstitutional in this instance. In other words, the Constitution might require the reallocation of Kraft's property entitlement to the word "cheese" to other speakers.

A closely analogous problem is at the center of copyright law, and here the Court's choice between Lochner- and Marsh-style reasoning is even more muddled. There has been much ink spilled about the effort to reconcile copyright protection with the First Amendment, ${ }^{177}$ but

176 See generally Michelle Fowler, Note, To Protect and ... to Profit: The Trademarking of the LAPD as an Example of Expanding Intellectual Property Rights, 74 S Cal L Rev 1623 (2001). In another well known example, Fox News tried to prevent comedian Al Franken from using the words "fair and balanced." See Susan Saulny, To Fox, "Fair and Balanced" Doesn't Describe Al Franken, NY Times B1 (Aug 12, 2003). The effort was unsuccessful. See Susan Saulny, In Courtroom, Laughter at Fox and a Victory for Al Franken, NY Times B5 (Aug 23, 2003). See also Caterpillar Inc $v$ Walt Disney Co, 287 F Supp 2d 913, 922 (CD Ill 2003) (rejecting an attempt to enjoin arguably unfavorable portrayal of Caterpillar tractors in movie); Wham-O Inc v Paramount Pictures Corp, 286 F Supp 2d 1254, 1264-65 (ND Cal 2003) (rejecting an attempt to enjoin arguably unfavorable portrayal of "slip-n-slide" in movie).

177 For examples of the scholarly literature, see David McGowan, Why the First Amendment Cannot Dictate Copyright Policy, 65 U Pitt L Rev 281, 291-94 (2004) (rejecting the argument that the First Amendment can limit the length and scope of copyright protection); Lawrence Lessig, Copyright's First Amendment, 48 UCLA L Rev 1057, 1070 (2001) (discussing changes in the conception of the values free speech is supposed to promote to include personal expression and noting the paradox of tightening copyright laws); Rebecca Tushnet, Copyright as a Model for Free Speech Law: What Copyright Has in Common with Anti-pornography Laws, Campaign Finance Reform, and Telecommunications Regulation, 42 BC L Rev 1, 4-67 (2000) (surveying the First Amendment arguments both for and against copyright); Yochai Benkler, Free as the Air to Common Use: First Amendment Constraints on the Enclosure of the Public Domain, 74 NYU L Rev 354, 358 
if Marsh and Lochner have really been disowned, it is hard to see what the difficulty is. What copyright amounts to is the discretionary allocation of property rights to the creators of copyrighted works. Without a constitutionalized property regime, there simply is no First Amendment problem. Just as I have no First Amendment right to burn someone else's flag, so too, one might suppose, I have no First Amendment right to sing someone else's song.

But, of course, there is a problem, and the Supreme Court has recognized as much. Although the Court has upheld copyright against First Amendment challenge, it has never suggested that the mere existence of a property right disposes of the issue. On the contrary, it has squarely rejected the proposition that copyrights are "categorically immune from challenges under the First Amendment." "178 Instead, it has held that the "traditional contours of copyright protection"179 satisfy free speech rights because of copyright's "built-in First Amendment accommodations." ${ }^{180}$ The Court has placed special emphasis on the fact that copyright protects only expression and not ideas and that the fair use exception to copyright "affords considerable "latitude for scholarship and comment,' and even for parody."

What are the justifications for these limits? Sometimes, the Court relies upon the same sort of Lochner-type reasoning that it has used in the trademark context. Creators of copyrighted works have a natural right to the fruits of their labors that is strong enough to ward off First Amendment concerns, at least in some contexts. ${ }^{182}$ On other occasions, though, the Court seems to have endorsed a Marsh-style property regime designed to maximize speech opportunities. Thus, the Court has claimed that copyright's allocation of property rights is an "engine of

(1999) (arguing that the First Amendment requires a robust public domain that exists outside of copyright protection); Melville B. Nimmer, Does Copyright Abridge the First Amendment Guarantees of Free Speech and Press?, 17 UCLA L Rev 1180, 1185 (1970) (explaining that analysis of First Amendment interests in the copyright context necessitates "definitional balancing").

178 Eldred $v$ Ashcroft, 537 US 186, 221 (2003). Compare Harper \& Row Publishers, Inc $v$ Nation Enterprises, 471 US 539, 556 (1985) (implying that a copyright law that protected ideas or facts would violate the First Amendment); International News Service v Associated Press, 248 US 215,234 (1918) (treating information regarding current events as not the creation of the writer).

179 Eldred, 537 US at 221.

180 Id at 219. See also Harper \& Row, 471 US at 560.

181 Eldred, 537 US at 220, quoting Harper \& Row, 471 US at 560.

182 See, for example, Harper \& Row, 471 US at 546 (noting that copyright law guarantees authors "a fair return for their labors"). For the best scholarly work in this tradition, see Wendy J. Gordon, A Property Right in Self-expression: Equality and Individualism in the Natural Law of Intellectual Property, 102 Yale L J 1533 (1993) (arguing that a Lockean theory of natural property rights in the intellectual property context would provide broad protections for free expression); Wendy J. Gordon, An Inquiry into the Merits of Copyright: The Challenges of Consistency, Consent, and Encouragement Theory, 41 Stan L Rev 1343 (1989) (analyzing several frameworks for evaluating copyright law). 
free expression." ${ }^{188}$ This is so, in the Court's view, because "[b]y establishing a marketable right to the use of one's expression, copyright supplies the economic incentive to create and disseminate ideas." The Court's claim, then, is not that the property allocations embodied in copyright law are immune from constitutional review but that these particular allocations best satisfy First Amendment values. ${ }^{1.5}$

Copyright might be thought to be a special case because of the Constitution's express endorsement of at least some sort of copyright regime, ${ }^{186}$ but courts have applied similar principles to creation of a state-law right to publicity with no underpinnings in the constitutional text. For example, in Zacchini v Scripps-Howard Broadcasting Co, ${ }^{187}$ the Court held that the media did not have a free speech right to broadcast Zacchini's entire, fifteen-second "human cannonball" act without compensating him. The Court once again relied on a mix of Lochner- and Marsh-style reasoning to reach this outcome. The state allocation of property interests was within the discretionary sphere both because Zacchini had created the act through his own efforts (a natural-law, Lochner-style justification) ${ }^{188}$ and because permitting him to control a property interest in his act provided appropriate incentives to develop the act (a Marsh-style speech maximization approach). ${ }^{189}$ While neither the Lochner nor Marsh property interest was sufficient to make the allocation mandatory, the interest was once again sufficiently powerful to move the allocation from the impermissible to the discretionary column.

Might these interests ever be sufficiently powerful to make the allocation mandatory? The Court seems to have at least suggested a mandatory allocation in Simon \& Schuster, Inc v Members of the New York State Crime Victims Board.$^{19}$ There, the Court invalidated a New York statute that required that the proceeds derived from a literary work created by a criminal that depicted the crime in question be reallocated to the victims of the crime. ${ }^{191}$ The Court, in effect, held that

183 Harper \& Row, 471 US at 558.

184 Id.

185 See Eldred, 537 US at 219. For a creative and convincing effort to develop general First Amendment principles from the example of copyright's speech-promoting qualities, see Tushnet, 42 BC L Rev at 35-37 (cited in note 177).

186 See US Const Art I, $\S 8, \mathrm{cl} 8$. Consider Eldred, 537 US at 219 (noting that "[t]he Copyright Clause and First Amendment were adopted close in time").

187433 US 562 (1977).

188 See id at 573 .

189 See id at 576.

190502 US 105 (1991).

191 See id at 123. 
allocation to the author of the profits gained by a literary work is constitutionally mandatory.

Perhaps Simon \& Schuster can be explained on the ground that the New York statute violated the formal requirement of content neutrality. The Court's discussion of this issue can be fairly characterized as garbled. It begins its analysis with the assertion that a "statute is presumptively inconsistent with the First Amendment if it imposes a financial burden on speakers because of the content of their speech" "192 and that "the [New York law] is such a content based statute." opinion, however, the Court states that it "need not address the Board's contention that the statute is content neutral" and that "whether the ... law is analyzed as content neutral... or content based... it is too overinclusive to satisfy the requirements of the First Amendment."194

There is no good way to resolve this contradiction, but it seems quite implausible that the statute would have survived constitutional scrutiny if it had been content-neutral and thereby applied to even more speech. If a statute that deprived criminals of royalties derived from their crimes is unconstitutionally overbroad, then surely a broader statute depriving ordinary authors of royalties regardless of the content of their work would be unconstitutional as well. It seems fair, therefore, to read Simon \& Schuster as establishing the principle that some kinds of market rewards for the creation of artistic work are constitutionally compelled. Put differently, this is a context where the Court treats the property allocations produced by the market for creative works as mandatory.

Conversely, it also seems reasonably clear that other protections for artistic work are impermissible. The Court has strongly suggested that a hypothetical copyright law that "altered the traditional contours of copyright protection," tinction or limiting fair use, would be subject to constitutional scrutiny. ${ }^{1.6}$ Here, some sort of reallocation of property rights from the creator to the copier are required in order to maximize free speech opportunities.

The bottom line, then, is that there seem to be some (admittedly illdefined) features of property allocations in the use and publication of works that are constitutionalized, both in the form of making copyright protection mandatory and making such protection impermissible.

192 Id at 115.

193 Id at 116.

194 Simon \& Schuster, 502 US at $122 \mathrm{n} *$.

195 Eldred, 537 US at 221.

196 See id at 219-20 ("[T]his 'idea/expression dichotomy strike[s] a definitional balance between the First Amendment and the Copyright Act by permitting free communication of facts while still protecting an author's expression."'), quoting Harper \& Row, 471 US at 556. 
Of course, the recognition of such limits is a long way from a fullblown reaffirmation of Marsh or Lochner. Copyright and trademark are arguably special cases because the property interest they recognize is in speech itself. It is one thing to say that there are limits on the extent to which the government can grant exclusive property interests in speech itself and quite another to say that a broader property rights scheme is unconstitutional because of its indirect effect on speech. What we are left with, then, is a strong suggestion that speech rights in this area are grounded in a constitutionalized property regime without a clear definition of either the contours of that regime or the extent to which the reasoning of these cases extends to other situations.

2. Libel and defamation, privacy invasion, and sexual harassment.

As just noted, copyright and trademark might be special cases because they involve the creation of property interests in speech itself. In contrast, constitutional limits on libel and defamation law, tort actions for invasion of privacy, and enforcement of pornography and antidiscrimination statutes seem to redistribute nonspeech entitlements. Instead of a property interest in speech, they involve a property interest in things like reputation, secrecy, or freedom from sexual or racial harassment. These entitlements are established by the common law or by statute, but the First Amendment shifts them (at least to some extent) so as to provide a constitutionally mandatory level of free expression. In this sense, cases like New York Times Co v Sullivan, ${ }^{197}$ Cox Broadcasting Corp v Cohn, ${ }^{198}$ and American Booksellers Association v Hudnut ${ }^{199}$ are in the Marsh tradition.

Consider first libel law. The common law of libel establishes a state-protected interest in one's reputation. One could imagine a Lochner-like argument that the protection of this interest is mandatory. At a minimum, though, protection should be discretionary under the terms of the New Deal compromise. Yet in certain contexts, Sullivan makes protection impermissible. The Court held that when a libel action is brought by a public figure, state allocation of an interest in reputation must give way to a constitutionally mandated redistribution unless

197376 US 254 (1964) (holding that libel recovery against a public figure violated the First Amendment unless the speaker proceeded with actual malice).

198420 US 469 (1975) (holding that recovery for invasion of privacy violated the First Amendment where the name of a deceased rape victim had been publicly revealed).

199771 F2d 323 (7th Cir 1985) (invalidating an ordinance that made the seller of pornographic literature liable for sexual harassment), affirmed, 475 US 1001 (1986). 
the speaker exhibits actual malice. ${ }^{200}$ Thus, Sullivan in effect reallocates property-like ownership rights so as to maximize speech opportunities.

Whereas the Sullivan rule reallocates property entitlements for public figures, cases like Cox Broadcasting suggest a similar reallocation with regard to private individuals. The Court has made clear that neither state common law rules nor criminal statutes can enforce an entitlement to information like the name of a deceased rape victim ${ }^{201}$ or the identity of a juvenile defendant, ${ }^{202}$ at least so long as the media lawfully obtains the information. Here, too, the Constitution creates a mandatory reallocation of entitlements so as to maximize speech freedom.

The story regarding sexual harassment is somewhat more complicated. When Indianapolis tried to create a property-like entitlement in freedom from the putative humiliation, degradation, and violence produced by pornography, the Seventh Circuit held that the entitlement had to be reallocated to pornographers so as to protect speech interests. ${ }^{203}$ In contrast, courts generally have been unsympathetic to the claim that Title VII's creation of an entitlement to be free from sexually harassing speech in the employment context is unconstitutional. $^{24}$ The creation of Title VII rights is not mandatory, but neither is it impermissible.

200 See Sullivan, 376 US at 267-82.

201 Cox Broadcasting, 420 US at 496-97. See also The Florida Star v BJF, 491 US 524,536-39 (1989) (holding that an award of damages against a newspaper that published lawfully obtained information about a rape victim violated the First Amendment).

202 See Smith v Daily Mail Publishing Co, 443 US 97, 104-05 (1979) (holding that barring publication of the name of a juvenile defendant does not further a "state interest of the highest order"); Oklahoma Publishing Co v District Court, 430 US 308, 310 (1977) (holding that a newspaper cannot be punished for reporting on public court proceedings, even in the case of a juvenile defendant). See also Bartnicki v Vopper, 532 US 514, 534 (2001) (holding that a newspaper could not be punished for publishing the transcript of an unlawfully intercepted telephone call where subject of the call was a matter of public concern).

203 Hudnut, 771 F2d at 332-34, affirmed, 475 US 1001.

204 See, for example, Piggee v Carl Sandberg College, 464 F3d 667, 672 (7th Cir 2006) (holding that a community college had a right to insist that an instructor refrain from distributing antihomosexuality religious literature to a homosexual student); Munro v Tristan, 116 Fed Appx 820, 821 (9th Cir 2004) (holding that a corrections department regulation banning materials containing nudity did not violate a prisoner's First Amendment rights); Baty v Willamette Industries, 172 F3d 1232, 1246-47 (10th Cir 1999) (declining to hold that a Title VII judgment against an employer violated the First Amendment); Robinson v Jacksonville Shipyards, Inc, 760 F Supp 1486, 1534-38 (MD Fla 1991) (noting that an employer's interest in maintaining a professional work environment may override an employee's interest in free expression). See generally Richard Fallon, Sexual Harassment, Content Neutrality, and the First Amendment Dog That Didn't Bark, 1994 S Ct Rev 1 (arguing that restrictions on sexually harassing speech may be more properly categorized as content-based rather than content-neutral, but nevertheless permissible). Compare Hishon $v$ King \& Spalding, 467 US 69, 78 (1984) (holding that private discrimination is not protected by the First Amendment right of association); Norwood v Harrison, 413 US 455 (1973) (same), with LaShaonda D. v Monroe County Board of Education, 526 US 629, 667 (1999) (Kennedy dissenting) ("A university's power to discipline its students for speech that may constitute 
What are we to make of these mixed results? Sullivan, Cox Broadcasting, and Hudnut are more radical than the copyright and trademark cases. First, in each case, the property-like interest trumped by the First Amendment is not in speech itself but in something else. It is one thing to say that the state may not defeat speech freedom by allocating to a narrow class of individuals the right to use certain words. It is quite a different matter to say that a speaker must be allowed to use someone else's nonspeech entitlements in order to get her message across. Yet this is just what Sullivan, Cox Broadcasting, and Hudnut require. I cannot destroy someone else's flag in order to make my political point, but apparently I can destroy someone else's reputation in order to sell newspapers.

Second, Sullivan, Cox Broadcasting, and Hudnut all involve Marshstyle rather than Lochner-style reasoning. In the copyright, publicity, and trademark contexts, the Court's constitutionalized property regime was at least partially premised upon respect for prepolitical distributions. In contrast, Sullivan, Cox Broadcasting, and Hudnut all require redistribution. For example, a person "owns" her reputation because of a lifetime of work creating and protecting it in the same sense that the USOC has invested in the word "Olympics." Yet Sullivan reallocates the right to someone who did not earn it in order to promote that person's speech opportunities. Similarly, one might have thought that a right to be free from sexual humiliation or the right to privacy about certain facts concerning one's life is an essential aspect of personhood, rather than merely a discretionary allocation of entitlements. Yet the Court treats these allocations as neither mandatory nor discretionary, but as impermissible, when they conflict with free speech interests.

Just because these results are more radical, they are also more problematic. They bring to the forefront questions about why constitutionally mandated redistributions are required here but not elsewhere. If newspapers can exact what amounts to a subsidy from the public figures they libel, why are they not also entitled to a constitutionally mandated redistribution from the paper companies that provide them with newsprint? Why, for that matter, are the flag makers not obligated to provide impoverished potential flag burners with the flags to burn?

sexual harassment is [ ] circumscribed by the First Amendment); Avis Rent A Car System, Inc $v$ Aguilar, 529 US 1138, 1138-44 (2000) (Thomas dissenting from denial of certiorari) (arguing that prior restraint of sexually harassing speech violates the First Amendment); Eugene Volokh, Freedom of Speech and Workplace Harassment, 39 UCLA L Rev 1791, 1843-58 (1992) (arguing that harassing speech not directed at a particular workplace member should be protected by the First Amendment).

205 Consider generally Lillian R. BeVier, The Invisible Hand of the Marketplace of Ideas, in Lee C. Bollinger and Geoffrey R. Stone, eds, Eternally Vigilant: Free Speech in the Modern Era 232 (Chicago 2002). 
These concerns, in turn, bleed over into the worry about constitutionalizing the entire social sphere. ${ }^{206}$ At the most general level, it is far from obvious that current distributions of wealth provide optimal speech opportunities. Why, then, does the reasoning of Sullivan, Cox Broadcasting, and Hudnut not lead to constitutionally mandated, broadbased income redistribution?

These worries intensify as soon as one realizes that when the scope of constitutionally mandated redistribution becomes this broad, it runs into other constitutional rights. Recall, for example, the suggestion in Simon \& Schuster that some reallocations of the proceeds from artistic creations are impermissible because they leave constitutionally inadequate incentives for the production of such works. ${ }^{208}$ Might not a similar argument be made about reputation? True, the media is engaged in First Amendment activity when they publish information about public figures, but public figures are also engaged in First Amendment activity when they do the things necessary to become public figures. If they are to be deprived of the rewards for their efforts - their reputation and everything that that entails-might not they be chilled from the exercise of their own speech rights?

No doubt, courts have been influenced by just this sort of concern when they have rejected free speech demands for reallocation of the right to be free from sexual harassment while on the job. To be sure, no court has held that Title VII protections are constitutionally mandatory, but the interest in freedom from sexual harassment is strong enough to ward off claims that it is constitutionally impermissible. ${ }^{209}$ Why, then, are not the interests of women in avoiding the humiliation, degradation, and violence allegedly produced by pornography similarly powerful? $?^{210}$

\section{Campaign finance.}

The Court has reached similarly mixed and inconclusive results concerning the regulation of campaign finance. Commentators often suppose that the issue concerning this regulation is whether the expenditure of money should count as "speech" within the meaning of

206 Consider Alexander, Freedom of Expression at 18 (cited in note 60) (arguing that the setting of marginal tax rates affects the amount of speech and, therefore, might be constitutionally compelled if the government were prohibited from enacting measures that limited speech).

207 Consider Gary Peller and Mark Tushnet, State Action and a New Birth of Freedom, 92 Georgetown L J 779, 793 (2004) (arguing that the "positive" conception of First Amendment rights leads to constitutionally mandated economic redistribution).

208 See notes 195-96 and accompanying text.

209 See notes 201-04 and accompanying text.

210 See, for example, Catharine A. MacKinnon, Reflections on Sex Equality under Law, 100 Yale L J 1281, 1325 (1991) (arguing that state protection of pornography is gendered action by the government). 
the First Amendment. ${ }^{211}$ Suppose, though, one concedes that the expenditure of money is not speech. The concession would not resolve the issue. The real controversy about campaign finance regulation is not about defining "speech," but about determining whether the government can shift nonspeech entitlements in a fashion that adversely impacts speech. ${ }^{2.2}$

Justice Antonin Scalia therefore directed our attention to just the right place when he argued that meaningful freedom of speech required fixed entitlements that can form the basis for market exchange:

It was said ... that since [campaign finance legislation] regulates nothing but the expenditure of money for speech, as opposed to speech itself, the burden it imposes is not subject to full First Amendment scrutiny.... In any economy operated on even the most rudimentary principles of division of labor, effective public communication requires the speaker to make use of the services of others.... Control any cog in the machine, and you halt the whole apparatus. License printers, and it matters little whether authors are still free to write.... What good is the right to print books without a right to buy works from authors? Or the right to publish newspapers without the right to pay deliverymen? The right to speak would be largely ineffective if it did not include the right to engage in financial transactions that are the incidents of its exercise.

These words appear in an opinion objecting to the Court's endorsement of the Bipartisan Campaign Reform Act of $2002^{214}$ (the socalled "McCain-Feingold" statute); but in fact, the Court has afforded some measure of constitutional protection against the regulation of campaign expenditures and has done so more forcefully since Justice Scalia wrote. ${ }^{215}$ When the Court has afforded this protection, it has done so by effectively constitutionalizing the property entitlements that make speech possible.

211 See, for example, David Skover, et al, Corporations and Political Speech: Should Speech Equal Money?, 30 Seattle U L Rev 931, 936 (2007); J. Skelly Wright, Politics and the Constitution: Is Money Speech?, 85 Yale L J 1001, 1010 (1976).

212 See, for example, Sunstein, 59 U Chi L Rev at 291-93 (cited in note 41) (arguing that Buckley v Valeo, 424 US 1 (1976), like Lochner, treats nonspeech entitlements as fixed).

213 McConnell v Federal Election Commission, 540 US 93, 250-52 (2003) (Scalia concurring in part and dissenting in part).

214 Bipartisan Campaign Reform Act of 2002, Pub L No 107-155, 116 Stat 81, codified at 2 USC $\$ 431$ et seq (2006).

215 See Federal Election Commission v Wisconsin Right to Life, Inc, $127 \mathrm{~S} \mathrm{Ct} 2652,2671-73$ (2007) (holding that a ban on corporate-sponsored "issue ads" before an election violated the First Amendment); Randall v Sorrell, 548 US 230 (2006) (refusing to overrule Buckley's holding that expenditure limits violate the First Amendment). 
Even before its most recent decision, the Court made clear that the First Amendment prevented the outlawing of personal expenditures, whether by the candidate herself or by a noncandidate acting independently. ${ }^{216}$ More recently, it has effectively gutted the provision in the McCain-Feingold statute outlawing so-called "issue ads" purchased by corporations in the immediate run-up to elections. ${ }^{217}$

These constitutional limits, in turn, rest on an implicit constitutionalization of property-like claims. The assumption behind the restrictions is that the money "belongs" to the entity making the expenditure and that the government is constitutionally prohibited from changing this entitlement. It does not take much work to see why this assumption is problematic.

Consider, for example, two campaign finance cases decided during the 2006 term. Davenport $v$ Washington Education Association ${ }^{218}$ arose in the context of an "agency-shop" agreement with a public sector union. Under the agreement, workers who did not join the union were nonetheless obligated to pay a fee to the union so as to prevent "free riding" on the union's efforts on behalf of the workers. ${ }^{219}$ The Court had previously held that the First Amendment prohibited a union from using fees collected from objecting nonmembers for ideological purposes not germane to the union's collective bargaining duties. ${ }^{220}$ In Davenport, the Court upheld a state statute requiring affirmative permission from dissenters before money could be so spent. ${ }^{221}$

In so holding, the Court found it "entirely immaterial that [the statute] restricts a union's use of funds only after those funds are already within the union's lawful possession under Washington law., ${ }^{222}$ Put differently, the Court held that the statute could constitutionally shift a state-recognized entitlement even though the shift impeded the union's First Amendment activities. In the Court's view, the statute was "not fairly described as a restriction on how the union can spend 'its' money; it is a condition placed upon the union's extraordinary state entitlement to acquire and spend other people's money." context, then, the analysis begins a step before the union gains ownership of the money, with the property entitlement vested in the nonmembers. State law permissibly shifts this entitlement to the union,

216 See Buckley, 424 US at 45 (holding that expenditure limits violated the First Amendment although contribution limits may be permissible).

217 See Wisconsin Right to Life, $127 \mathrm{~S} \mathrm{Ct}$ at 2670.

218127 S Ct 2372 (2007).

219 Id at 2376-77.

220 See Abood v Detroit Board of Education, 431 US 209, 232-37 (1977).

221 Davenport, $127 \mathrm{~S} \mathrm{Ct}$ at 2383.

222 Id at 2380 .

223 Id. 
but on the constitutionally mandatory condition that it not be spent for political purposes over the objection of the nonmembers and the constitutionally permissible condition that it not be spent without their affirmative approval.

Compare this outcome to the result reached in a much more widely publicized case, Federal Election Commission $v$ Wisconsin Right to Life, Inc. ${ }^{24}$ Here, the Court upheld a case-specific challenge to the McCain-Feingold statute, which prohibited expenditures by corporations for so-called "issue ads" broadcast close to election day. ${ }^{2.5}$ This time, for reasons that are not explained, the Court's analysis begins a step later than in Davenport, with the money already "belonging" to the corporation rather than in the hands of the individuals who provide it to the corporation. ${ }^{226}$ The regulation of the corporation's speech expenditures is therefore a limitation on the use of "its" money, constituting an unconstitutional shift of the entitlement.

What, precisely, is the difference between the two cases? An obvious answer is that in Davenport, the union got the money in the first place only because of state coercion. The government had negotiated a contract providing for an agency-shop arrangement that compelled employees to contribute money to the union. In contrast, no one is compelled to buy stock in or contribute money to a corporation. But this response again begs the question of which stage of the transaction should be focused on. Just as no one is compelled to buy stock in a corporation, so too, no one is compelled to accept a job from an employer who has agreed to an agency-shop arrangement. Once one accepts the job, certain obligations come with it. True, some of those obligations may be ideologically distasteful, but that is true as well of someone who contributes money to a corporation and then finds that the corporation has spent the money to support ideological positions that the contributor opposes.

Perhaps, then, the point is that the government may not condition the benefit of employment on the sacrifice of ideological positions, ${ }^{27}$ whereas private corporations can so condition stock ownership. The Davenport Court reserved the question whether the affirmative permission requirement could be imposed in the case of nonstate em-

$224127 \mathrm{~S} \mathrm{Ct} 2652$ (2007).

225 Id at 2659.

226 Id at 2663-64.

227 Compare, for example, Pickering v Board of Education of Township High School District 205, 391 US 563, 568 (1968) (providing some First Amendment protection for government employees), with Snepp v United States, 444 US 507, 510 (1980) (holding that a former CIA agent could be constitutionally bound to an agreement, signed as condition of employment, not to publish material without the prior approval of the agency). 
ployers, ${ }^{228}$ and the Court's earlier treatment of the issue has not clearly established the extent to which the governmental status of the employer matters. ${ }^{29}$ If the Court ends up extending Davenport to private employers, it is hard to see how its holding can be reconciled with Wisconsin Right to Life.

Moreover, even if Davenport is confined to public employers, the distinction it depends upon enmeshes us again in the confused case law concerning the failure to provide government benefits. As we have already seen, it will not do to say that the government may never condition access to benefits on the funding of ideologically distasteful speech. ${ }^{200}$ Nor can it be claimed that people generally have the right to avoid coerced contributions to ideological speech they oppose. For example, the Court has upheld against First Amendment attack stateimposed mandatory student activity fees that fund ideologically charged activities. ${ }^{231}$ Indeed, during the very term in which Davenport was decided, the Court held that an athletic association, deemed to be a state actor, could condition "voluntary" membership on the relinquishment of the right to engage in activity that would otherwise be protected by the Free Speech Clause. ${ }^{232}$ Why, then, is the government precluded from conditioning voluntary employment on a willingness to acquiesce in the use of union dues for ideological purposes?

Nor is it clear which way the unconstitutional condition argument cuts. Recall that the union also advanced an unconstitutional condition argument. It claimed that its access to the funds in question was unconstitutionally conditioned on its forgoing use of the funds for activities otherwise protected by the First Amendment. Why is this condition constitutionally permissible, while conditioning access to a job is not?

However these anomalies are resolved, the important point for our purposes is that free speech protection in this area turns on the willingness of the Court to fix property entitlements. When it does so, as in Wisconsin Right to Life, the result is a robust free speech

228 See Davenport, $127 \mathrm{~S} \mathrm{Ct}$ at 2382 ("Since private-sector unions collect agency fees through contractually required action taken by private employers, rather than by government agencies, Washington's regulation of those private agreements presents a somewhat different constitutional question.").

229 See Abood, 431 US at 226-37. The case establishing the right of employees not to contribute to union-supported ideological causes arose in the context of a government employer. Earlier, the Court had established a similar right in the case of a private employer, but it had done so as a matter of statutory construction. See Machinists v Street, 367 US 740, 759-61 (1961).

230 See notes 143-44 and accompanying text.

231 See Board of Regents of the University of Wisconsin System v Southworth, 529 US 217, 221 (2000) (holding that a mandatory student activities fee did not violate the First Amendment as long as funds were distributed in a viewpoint-neutral way).

232 See Tennessee Secondary School Athletic Association v Brentwood Academy, $127 \mathrm{~S} \mathrm{Ct}$ $2489,2495-96$ (2007). 
regime. When it fails to do so, in cases like Davenport, free speech rights evaporate.

Moreover, when it chooses the constitutionalization option, it confronts all the problems that gave rise to the New Deal compromise in the first place. Chief among these is how to fix property rights without constitutionalizing the entire social sphere. Justice Scalia is surely correct when he claims that it does no good to publish a newspaper if one cannot pay the deliveryman, but what if, say, one lacks the money to pay the deliveryman because government-imposed payroll taxes make the payment prohibitively expensive? ${ }^{233}$

The government malfunction test provides a potential answer to this problem. When the government prohibits spending money for campaign speech, it is acting nonneutrally in the sense that it is limiting expenditures for speech but not other types of spending. When it imposes a social security tax, its regulation is unrelated to and facially neutral with regard to speech. The problem with this response, however, is that it begs the question whether speech-specific regulation is really evidence of malfunction. There is no particular reason to think that unregulated or neutrally regulated markets in nonspeech commodities will produce the optimal level of speech. It is at least possible that the people with more money will outbid the people with more to say for the services of the deliveryman. ${ }^{24}$

This problem intersects with a second difficulty: why are the entitlements in question of the Lochner rather than the Marsh variety? ? $^{235}$ If it is indeed true that a speech right is meaningless without the abili-

233 Consider Susan H. Williams, Content Discrimination and the First Amendment, $139 \mathrm{U} \mathrm{Pa}$ L Rev 615, 724 (1991) (arguing that regulation of access to paper and typewriters raises First Amendment issues, but that "without some limit, the free speech guarantee would be transformed into an invitation for all speakers to violate any generally applicable law if the violation contributes in any way, no matter how indirect, to their ability to speak").

234 See, for example, J.M. Balkin, Some Realism about Pluralism: Legal Realist Approaches to the First Amendment, 1990 Duke L J 375, 411 ("It becomes problematic to claim that the state has not exercised a substantive choice when a William Loeb or Ruppert [sic] Murdoch can reach a large number of people, and persons with opposite but equally extreme views can reach very few."). Some commentators argue that campaign contribution and expenditure regulation should be suspect because government actors will sometimes use their power to retard, rather than promote, free speech. See, for example, Elena Kagan, Private Speech, Public Purpose: The Role of Governmental Motive in First Amendment Doctrine, 63 U Chi L Rev 415, 467-75 (1996) (arguing that the principle enunciated in Buckley helps uncover illicit congressional motives); Lillian R. BeVier, Money and Politics: A Perspective on the First Amendment and Campaign Finance Reform, 73 Cal L Rev 1045, 1071-76 (1985) (arguing that proponents of campaign finance reform face problems justifying those reforms with respect to the First Amendment and noting that those reforms may be self-interested and suspect). This concern is no doubt legitimate, but those who voice it have not explained why the failure to redistribute from a market baseline is immune from their skepticism about the motives of government actors.

235 See Sunstein, 59 U Chi L Rev at 263-92 (cited in note 41). 
ty to control other entitlements that make speech possible, then why is there not a government obligation to provide the other entitlements? ${ }^{236}$ If the government were so obligated then some forms of campaign regulation-perhaps a "free speech voucher" to be spent on the candidate of one's choice - would be constitutionally mandatory rather than impermissible.

Here as elsewhere, the Court has resolved these difficulties mostly by ignoring them. It has sometimes treated entitlements as constitutionally fixed so as to provide First Amendment protection and sometimes treated them as constitutionally discretionary, so as to defeat First Amendment claims. And without any real discussion, and contrary to the tenets of the New Deal compromise, when it has treated them as fixed, it has generally assumed that they are Lochner-style rather than Marsh-style entitlements.

4. Public fora and other "as-applied" cases.

In sharp contrast to its campaign finance jurisprudence, the Court's public forum doctrine makes some property regimes constitutionally impermissible. Marsh-style transfers are therefore constitutionally mandatory.

In the campaign finance cases, the Court has granted First Amendment protection to market distributions. Thus, in Wisconsin Right to Life, the Court starts with the assumption that it is the corporation's money, and restrictions on corporate expenditures are therefore constitutionally problematic. The Court has ignored the objection that we might facilitate more speech by transferring entitlement to money to other entities. Indeed, when states attempt such transfers, as in Davenport, the transfer itself is treated as constitutionally troublesome.

In contrast, public forum cases proceed on the assumption that allowing pure market distributions of nonspeech entitlements may provide insufficient speech opportunities. For this reason, the Court has read the First Amendment as requiring a kind of free speech subsidy in the form of constitutionally mandatory private use of government property for speech purposes.

The law of the public forum is complex, inconsistent, and notoriously subject to manipulation. I will not attempt to summarize all of the doctrine here. ${ }^{237}$ However, two points stand out. First, citizens have

236 See Peller and Tushnet, 92 Georgetown $\mathrm{L} J$ at 793-95 (cited in note 207).

237 For an introduction, see generally Kalven, $1965 \mathrm{~S} \mathrm{Ct} \mathrm{Rev} 1$ (cited in note 82). See also generally Ronald A. Cass, First Amendment Access to Government Facilities, 65 Va L Rev 1287 (1979) (examining the public forum doctrine and suggesting changes to it); Geoffrey R. Stone, Fora Americana: Speech in Public Places, 1974 S Ct Rev 233 (tracing the history of the public forum doctrine). 
no general constitutional right to use public property for First Amendment activities. For example, the Court has held that the First Amendment does not protect the right of protestors to use the property immediately adjacent to a jail house. ${ }^{238}$ In this context, then, speech rights are discretionary because they are dependent on preexisting property rights that the government is free to shift (at least so long as it does so in content-neutral fashion).

The first point is qualified by a second point, however. In the case of "quintessential" or "traditional" public fora-streets, sidewalks, and parks - the government is constitutionally required to provide some access in order to facilitate First Amendment activity. ${ }^{239}$ Moreover, when the government opens a nontraditional area to speech activitythereby creating a "designated forum"-it is limited in the extent to which it can pick and choose among speakers. ${ }^{240}$ To be sure, the access to both traditional and designated fora can be regulated in a variety of ways. In the case of traditional fora, however, restrictions must also be "narrowly tailored to serve a significant government interest, and leave open ample alternative channels of communication." prohibition of a particular kind of expression is permissible only if it is "narrowly drawn to accomplish a compelling governmental interest."

In this context, then, the Constitution makes an unfettered government property right impermissible. There is a constitutionally compelled redistribution from the government to speakers in order to facilitate communication.

Ironically, the redistributive thrust of public forum law is best captured in a dissenting opinion. Objecting to the Court's refusal to invalidate a statute that prohibited persons from using a sound truck

238 See Adderley v Florida, 385 US 39, 47 (1966):

Nothing in the Constitution of the United States prevents Florida from even-handed enforcement of its general trespass statute against those refusing to obey the sheriff's order to remove themselves from what amounted to the curtilage of the jailhouse. The State, no less than a private owner of property, has the power to preserve the property under its control for the use to which it is lawfully dedicated.

239 See, for example, United States v Grace, 461 US 171, 183-84 (1983) (invalidating a statute that prevented the display of signs on the sidewalks around the Supreme Court building on the ground that sidewalks are traditional public fora); Southeastern Promotions Ltd v Conrad, 420 US 546, 556-57 (1976) (holding that when a municipality operated a public theater, the denial of a petition to produce a musical constituted an unlawful prior restraint when there were no ascertainable standards for selection of presented materials); Schneider $v$ New Jersey, 308 US 147, 151-52 (1939) (reversing convictions for distributing handbills on public streets). For the seminal academic treatment of the issue, see Kalven, $1965 \mathrm{~S} \mathrm{Ct} \mathrm{Rev} \mathrm{at} \mathrm{22-25} \mathrm{(cited} \mathrm{in} \mathrm{note} \mathrm{82).}$

240 See Perry Education Association v Perry Local Educators' Association, 460 US 37, $45-46$ (1983) (holding that it was reasonable for a school district to exclude a rival union's communications once one union was certified as the district representative).

241 Grace, $461 \mathrm{US}$ at 176.

242 Id at 177. 
or other instrument emitting "loud and raucous noises," Justice Black wrote that

unless constitutionally prohibited, laws like this Trenton ordinance can give an overpowering influence to views of owners of legally favored instruments of communication. This favoritism, it seems to me, is the inevitable result of today's decision.... There are many people who have ideas that they wish to disseminate but who do not have enough money to own or control publishing plants, newspapers, radios, moving picture studios, or chains of show places. Yet everybody knows the vast reaches of these powerful channels of communication which from the very nature of our economic system must be under the control and guidance of comparatively few people. On the other hand, public speaking is done by many men of divergent minds with no centralized control over the ideas they entertain so as to limit the causes they espouse. It is no reflection on the value of preserving freedom for dissemination of the ideas of publishers of newspapers, magazines, and other literature, to believe that transmission of ideas through public speaking is also essential to the sound thinking of a fully informed citizenry. ${ }^{2 / 3}$

It would be a mistake to overstate the extent of the redistributive thrust of public forum law. After all, Justice Black's opinion was a dissent. Moreover, in recent years, the Court has substantially limited the reach of public forum doctrine. It has resisted the expansion of the category of "traditional" fora ${ }^{24}$ and, even within the category, has upheld restrictive permit regimes and extensive "time, place, and manner" restrictions (like the ban on sound trucks). ${ }^{245}$ Moreover, the Court has begun to define designated fora in a disturbingly circular way, treating the very restrictions under attack as conclusively establishing that the forum has not been designated for speech in the first place. ${ }^{246}$

243 Kovacs v Cooper, 336 US 77, 102 (1949) (Black dissenting).

244 See, for example, Cornelius $v$ NAACP Legal Defense and Education Fund, 473 US 788, 802-06 (1985) (holding that a charity fundraising drive for federal employees was not a public forum); Taxpayers for Vincent, 466 US at 813-14 (holding that a publicly owned utility pole was not a public forum); Heffron $v$ International Society for Krishna Consciousness, 452 US 640, 650-52 (1981) (distinguishing fairgrounds from public streets).

245 See, for example, Cox v New Hampshsire, 312 US 569, 575-76 (1941) (upholding a permit regime requiring a license before holding a "parade" or "procession" on public street); Clark $v$ Community for Creative Non-violence, 468 US 288, 292-94 (1983) (upholding ban on sleeping in a public park as means of protest); Ward $v$ Rock against Racism, 491 US 781, 792-93 (1989) (upholding noise control measures in a public park).

246 See Cornelius, 473 US at 813-14 (Blackmun dissenting) (criticizing the Court for circular reasoning in holding that a charity drive was "not a limited public forum because the Govern- 
Even as so limited, though, the doctrine continues to have considerable bite. The most significant point is that, at least in the case of traditional fora, the requirement is not merely formal. Content neutrality is a necessary but insufficient condition for restricting speech in this context. Public forum doctrine is therefore an unusual example of as-applied constitutionalism. The constitutionally guaranteed subsidy takes hold even if the government policy lacks the usual indicia of government malfunction.

Moreover, although the level of judicial scrutiny is sharply reduced once outside the realm of traditional fora, even in these situations, the Court continues to evaluate the reasonableness of government limitations, occasionally invalidating even neutral restrictions when they allow insufficient quantities of speech. ${ }^{24}$

Why have Marsh-like constitutionally mandatory redistributions survived in this area when they are not required elsewhere? Perhaps the point is that the Constitution requires reallocation of government

ment intended to limit the forum to a particular class of speakers"). See also Tribe, Constitutional Law at 996 (cited in note 90):

This effectively turned the public forum doctrine on its head: carried to its logical conclusion, it would make nearly all restrictions on speech self-justifying, since the very fact that the government had denied the plaintiff access could be invoked to prove that the government never intended to create a public forum.

247 See, for example, note 239.

248 As Professor Tribe has written:

[A]t least since 1939, it has been established that even a wholly neutral government regulation or policy, aimed entirely at harms unconnected with the content of any communication, may be invalid if it leaves too little breathing space for communicative activity, or leaves people with too little access to channels of communication, whether as would-be speakers or as would-be listeners.

Tribe, Constitutional Law at 978 (cited in note 90).

The canonical test for "neutral" government actions that incidentally impact speech was stated in United States $v O^{\prime}$ Brien, where the Court emphasized that the government interest must be "important or substantial" and "the incidental restriction on alleged First Amendment freedoms [must be] no greater than is essential to the furtherance of that interest." See 391 US 367 , 371 (1968). Despite the seeming stringency of this requirement, in practice the Court has often imposed only relaxed scrutiny in these situations, leading to validation of the questioned policy. See, for example, City of Erie v Pap's A.M., 529 US 277, 278-80 (2000) (upholding as contentneutral a public indecency statute against a First Amendment challenge from the operator of a nude dancing establishment); Grayned $v$ Rockford, 408 US 104, 113-14 (1972) (upholding an antinoise ordinance that prohibited disturbing the peace near schools while the schools were in session). The most dramatic instances where the Court has employed more restrictive scrutiny of such measures involve speech using "quintessential" public fora. See, for example, note 239. On occasion, however, the Court has invalidated such measures even when they do not involve use of public fora. See, for example, Gilleo, 512 US at 55 (holding a measure that prevented posting of signs on one's own property unconstitutional despite the measure's content neutrality); Simon \& Schuster, 502 US at 118 (invalidating a measure that deprived criminals of proceeds derived from literary works despite the measure's content neutrality). See also Alexander, Freedom of Expression 16 (cited in note 60) (arguing that the Court employs the same test in public forum and symbolic speech cases). 
property but not property held by private individuals. As in the campaign finance context, however, this distinction depends on specifying the point at which the analysis begins. As Republicans never tire of telling us, tax dollars belonged to private individuals before the government took them. Why do these private individuals not have $D a$ venport-like rights to object to its reallocation to subsidize ideological causes they oppose?

Moreover, on admittedly rare occasions, the Court has required redistributions even with respect to private property. Consider, for example, Denver Area Educational Telecommunications Consortium, Inc $v$ FCC. ${ }^{249}$ At issue was a federal statute that authorized private cable operators to prohibit "indecent" programming over leased channels, which federal law requires cable operators to reserve for commercial use by third parties, and public access channels, which local governments have required cable operators to carry.

A badly fractured Court upheld the leased channel provision and struck down the public access provision..$^{250}$ For present purposes, the important point is that a majority of the justices seem to have assumed that both provisions were subject to constitutional challenge even though they did no more than reaffirm the right of the private cable company to exercise editorial control. ${ }^{251}$ Although the leased channel provision ended up surviving this First Amendment scrutiny, the public access provision did not survive. The outcome is public forum law seen through the looking glass. Instead of mandating redistribution from the government to private speakers, the Constitution in this context requires redistribution from private speakers to the government.

Denver is surprising in a second respect as well. As we have seen, the fact that broadcast licenses are themselves the product of regulation has made them seem like "new" property. ${ }^{252}$ In cases like Red Lion, the Court has emphasized this factor to shift the analysis from the mandatory (Lochner) sphere to the permissive sphere. Thus, the fairness doctrine is constitutionally permissible but not constitutional-

249518 US 727 (1996).

250 See id at $732-33$.

251 See id at 737, 740-53 (Breyer plurality with Stevens, O'Connor, and Souter) (recognizing that "the First Amendment, the terms of which apply to governmental action, ordinarily does not itself throw into constitutional doubt the decisions of private citizens to permit, or to restrict, speech" but nonetheless resolving the free speech question with regard to the leased channel provisions on the merits); id at 760 (Breyer plurality with Stevens and Souter) (invalidating a public access provision despite its permissive nature); id at 782 (Kennedy concurring in part and dissenting in part) (arguing that both provisions are unconstitutional state action despite their permissive nature because "[s]tate action lies in the enactment of a statute altering legal relations between persons, including the selective withdrawal from one group of legal protections against private acts").

252 See Part II.B.1. 
ly required. In contrast, Denver goes the whole way by moving the analysis all the way to the impermissible (Marsh) sphere. The destabilization of traditional property concepts produced by pervasive regulation not only defeats Lochner-like claims to constitutionally protected private ownership but, contrary to the New Deal compromise, also makes such ownership impermissible.

It bears emphasis that Denver is aberrational and easily cabined. Although Justice Stephen Breyer's plurality opinion suggests a willingness to consider constitutionally mandatory redistribution in the broadcasting context, ${ }^{233}$ the votes necessary to make a majority were cast by Justices Anthony Kennedy and Ruth Bader Ginsburg, who adopted a formal approach, emphasizing the fact that the selective grant of permissive authority was content-based. ${ }^{244}$ And although there are a smattering of other cases outside of the public forum category where the Court has used as-applied analysis to make existing distributions impermissible ${ }^{255}$ the dominant method of review remains formal.

It should be emphasized as well how limited public forum law is. Perhaps the most disturbing limitation is the requirement that the forum be "traditional." In fact, recent scholarship makes clear that we have retreated a long way from the kind of free speech access to streets and parks that our eighteenth and nineteenth century traditions permitted. ${ }^{36}$ But even if the Court had been more protective of our traditions, the traditional forum approach fails to account for how modes of communication change over time. As these changes occur, traditional modes inevitably lose importance. In the eighteenth century, streets and parks were the primary loci for speech. Today, the primary locus is the electronic media. If we are to preserve the speech opportunities that existed at the founding, we need to provide people with internet connections as well as public parks.

There is no mystery as to why the Court has nonetheless been eager to cabin the requirement of Marsh-like redistributions, or, for that matter, Lochner-like protections of existing distributions. We are back to the dilemma we started with. The failure to cabin these doctrines would lead to the judicialization of the entire political sphere, thereby violating one branch of the New Deal compromise.

But although these doctrines have not been expanded, neither have they been repudiated. Cases like Denver demonstrate that they

253 See Denver, 518 US at 737, 740-53 (Breyer plurality, with Stevens, O'Connor, and Souter).

254 See id at 782 (Kennedy, joined by Ginsburg, concurring in part, concurring in the judgment in part, and dissenting in part).

255 See text accompanying notes 194-95.

256 See generally Tabatha Abu El-Haj, The Neglected Right of Assembly, 56 UCLA L Rev (forthcoming 2009). 
still have life. There is no mystery about their survival, either. Total extirpation of these doctrines would lead to making all First Amendment claims discretionary, thereby violating the other branch of the New Deal compromise. The upshot is that sometimes the Court treats property rights as constitutionally fixed and sometimes it does not. When does it reach one result and when the other? Part IV offers some speculations on this subject.

\section{THE INVISIBLE FIRST AMENDMENT}

In this final Part, I address a puzzle that lies at the core of my argument. If that argument is correct, then there is a sense in which First Amendment rights are impossible. This is so because we are committed to a discretionary property regime, and such a regime entails a discretionary speech regime. Why, then, does it appear to so many of us that we have a remarkably robust free speech culture protected by constitutionally fixed First Amendment rules?

There are two responses to this paradox. The first response is that we are less committed to a discretionary property regime than we think we are. The second is that we are less committed to a robust free speech regime than we think we are. I explore these responses separately below.

\section{A. Discretionary Property?}

Consider first our supposedly discretionary property regime. Free speech rights thrive only when we deviate from the New Deal compromise by constitutionalizing either Lochner or Marsh property entitlements. But in fact, as Part III demonstrates, we have deviated quite a bit. We do seem to treat some property rights as constitutionally fixed in areas like intellectual property, libel, campaign finance, and public forum doctrine.

This response, in turn, raises a question of its own. When are economic entitlements constitutionalized, and when do they remain discretionary? Writing over thirty years ago, Bruce Ackerman attempted to understand our constitutional practices regarding private property by comparing the perspective of the ordinary observer with that of the scientific policymaker. For the ordinary observer "the test of a sound legal rule is the extent to which it vindicates the practices and expectations embedded in, and generated by, dominant social institutions." In contrast, for the scientific policymaker " $[t]$ he rules of the system are

257 See Bruce A. Ackerman, Private Property and the Constitution 12 (Yale 1977) (discussing the concept of a "Comprehensive View," in which the content of laws will be judged by the extent to which they conform to the observer's views of how the legal system should function). 
understood to be the product of legislative and judicial efforts to implement [a] Comprehensive View in the best practical way." ${ }^{, 258}$ On the speech side of the ledger, Robert Post has made similar, although not identical, observations. He has contrasted an approach that sees speech as embedded in and formed by a set of social practices on the one hand with an approach that treats these rights as formed by a coherent set of legal rules on the other. ${ }^{25}$

Suppose we view our problem from the ordinary-observer-social practices perspective. Then the answer to our question about when property and, therefore, speech rights are constitutionalized lies outside of law. The distinction between fixed and discretionary rights is no more (and no less) than a social fact. The fact is contingent, but it is nonetheless extremely powerful. As things stand now, it simply seems to us that the Boy Scouts belong to BSA, rather than to Dale. This is the first sense in which we have an invisible First Amendment. The contours of the doctrine are formed by a set of social understandings that are so thoroughly internalized that they do not even come into our consciousness.

Of course, a scientific policymaker is not going to be satisfied with this response. She will want to dig deeper by asking where these social practices come from. As a positive matter, one might see them as emerging from a comprehensive view that drives and explains the law. As a normative matter, one might be able to get critical traction by comparing them to a comprehensive view that we should, but have not, adopted.

What sort of comprehensive view might be at work? Given my own biases, I am drawn to a view that emphasizes the material, class, and social circumstances of the winners and losers produced by our invisible social practices. It is no accident, on this view, that Wisconsin Right to Life is about corporations, while Davenport is about unions, or that Dale, San Francisco Arts and Athletics, and Rust are about the rights of women and gays, while Rosenberger is about the rights of Christians.

I have to concede, though, that this is not the only way to organize the data. I am sure one could tell stories about efficiency, natural rights, historicism, or any of a host of other approaches that would also explain the cases. When I try to step away from my own biases, it becomes apparent that our social practices are simply too complex and subject to too many cross-currents to be captured by any simple structural theory. Yes, the unions lost in Davenport, but unions also

258 Id at 11.

259 See Robert Post, Recuperating First Amendment Doctrine, 47 Stan L Rev 1249, 1272 (1995) (arguing against ascribing one particular value, like "self-governance," that free speech is supposed to protect). 
joined corporations in opposing the section of the McCain-Feingold statute invalidated in Wisconsin Right to Life.

This complexity, in turn, suggests that the rigidity of scientific explanations may make them both descriptively inaccurate and counterproductive. A comprehensive view provides a grounding for critique, but ironically, it also can make critique seem pointless. Such a view suggests that the current state of affairs is driven by overpowering forces that prevent change.

\section{B. Robust Free Speech Rights?}

Here, I want to introduce a second sense in which the First Amendment is invisible as well as a second response to the paradox of a seemingly robust First Amendment culture linked to a doctrinal framework that is incompatible with speech rights. Once we get over a belief grounded in a comprehensive view that things must be the way they are, we can begin to see that our free speech culture may not be as robust as we imagine it to be. We see plenty of speech around us, but there is simply no way to know how much more speech, or what different kinds of speech, there might be if we had a different set of property entitlements. Our First Amendment regime is invisible in the sense that we cannot see or know what our public debate would look like in a possible alternative world where we stuck more closely to either a Lochner or Marsh regime.

If I am right that the social forces that have produced the current regime are too complex and subject to too many cross-currents to be captured in a single comprehensive view, then that regime may well be more subject to change than it appears to be. Instead of being the product of a single, overpowering cause, it may result from a fragile confluence of forces. Any attempt to imagine a different, more robust speech regime that might accompany different property distributions could conceivably upset this balance.

This hope-it is no more than that-provides the motivation for tracing through the difficult analytic structures outlined in this Article. The first step in imagining an alternative free speech regime is to see the contradictions and vulnerability at the core of the regime we currently have. And the first step in doing that is to understand why our current First Amendment doctrine cannot resolve the Dale problem.

260 See Brief of Amicus Curiae, American Federation of Labor and Congress of Industrial Organizations, supporting Appellee, Federal Election Commission v Wisconsin Right to Life, Nos 06-969, 06-970, *23-26 (filed Mar 23, 2007), available online at 2007 WL 894819 (arguing that there is no legitimate government interest in prohibiting labor unions from running "issue ads" referencing a particular candidate). 